Atmos. Chem. Phys., 19, 8721-8739, 2019

https://doi.org/10.5194/acp-19-8721-2019

(C) Author(s) 2019. This work is distributed under

the Creative Commons Attribution 4.0 License.

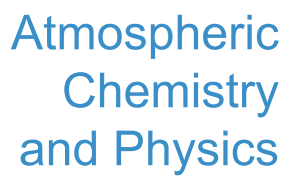

(c) (i)

\title{
Is water vapor a key player of the wintertime haze in North China Plain?
}

\author{
Jiarui Wu ${ }^{1,4,7}$, Naifang Bei ${ }^{2}$, Bo Hu${ }^{3}$, Suixin Liu ${ }^{1,4}$, Meng Zhou ${ }^{5}$, Qiyuan Wang ${ }^{1,4}$, Xia $\mathbf{L i}^{1,4,7}$, Lang Liu ${ }^{1,4,7}$, \\ Tian Feng ${ }^{1}$, Zirui Liu ${ }^{3}$, Yichen Wang ${ }^{1}$, Junji Cao ${ }^{1,4}$, Xuexi Tie ${ }^{1,4}$, Jun Wang ${ }^{5}$, Luisa T. Molina ${ }^{6}$, and Guohui Li ${ }^{1,4}$ \\ ${ }^{1}$ Key Lab of Aerosol Chemistry and Physics, SKLLQG, Institute of Earth Environment, Chinese Academy of Sciences, \\ Xi'an, Shaanxi, 710061, China \\ ${ }^{2}$ School of Human Settlements and Civil Engineering, Xi'an Jiaotong University, Xi'an, Shaanxi, 710049, China \\ ${ }^{3}$ State Key Laboratory of Atmospheric Boundary Layer Physics and Atmospheric Chemistry, Institute of Atmospheric \\ Physics, Chinese Academy of Sciences, Beijing, 100029, China \\ ${ }^{4}$ CAS Center for Excellence in Quaternary Science and Global Change, Xi' an, Shaanxi, 710061, China \\ ${ }^{5}$ Department of Chemical and Biochemical Engineering \& Interdisciplinary Graduate Program in Geo-Informatics, \\ University of Iowa, Iowa City, Iowa, IA 52242, USA \\ ${ }^{6}$ Molina Center for Energy and the Environment, La Jolla, California, CA 92037, USA \\ ${ }^{7}$ University of Chinese Academy of Science, Beijing, 100049, China
}

Correspondence: Guohui Li (ligh@ieecas.cn)

Received: 12 December 2018 - Discussion started: 14 February 2019

Revised: 26 May 2019 - Accepted: 6 June 2019 - Published: 10 July 2019

\begin{abstract}
Water vapor has been proposed to amplify the severe haze pollution in China by enhancing the aerosolradiation feedback (ARF). Observations have revealed that the near-surface $\mathrm{PM}_{2.5}$ concentrations $\left(\left[\mathrm{PM}_{2.5}\right]\right)$ generally exhibit an increasing trend with relative humidity $(\mathrm{RH})$ in the North China Plain (NCP) during 2015 wintertime, indicating that the aerosol liquid water (ALW) caused by hygroscopic growth could play an important role in the $\mathrm{PM}_{2.5}$ formation and accumulation. Simulations during a persistent and heavy haze pollution episode from 5 December 2015 to 4 January 2016 in the NCP were conducted using the WRFChem Model to comprehensively quantify contributions of the ALW effect to near-surface $\left[\mathrm{PM}_{2.5}\right]$. The WRF-Chem Model generally performs reasonably well in simulating the temporal variations in RH against measurements in the NCP. The factor separation approach (FSA) was used to evaluate the contribution of the ALW effect on the ARF, photochemistry, and heterogeneous reactions to $\left[\mathrm{PM}_{2.5}\right]$. The ALW not only augments particle sizes to enhance aerosol backward scattering but also increases the effective radius to favor aerosol forward scattering. The contribution of the ALW effect on the ARF and photochemistry to near-surface $\left[\mathrm{PM}_{2.5}\right]$ is not significant, being generally within $1.0 \mu \mathrm{g} \mathrm{m}^{-3}$ on av-
\end{abstract}

erage in the NCP during the episode. Serving as an excellent substrate for heterogeneous reactions, the ALW substantially enhances the secondary aerosol (SA) formation, with an average contribution of $71 \%, 10 \%, 26 \%$, and $48 \%$ to near-surface sulfate, nitrate, ammonium, and secondary organic aerosol concentrations. Nevertheless, the SA enhancement due to the ALW decreases the aerosol optical depth and increases the effective radius to weaken the ARF, reducing near-surface primary aerosols. The contribution of the ALW total effect to near-surface $\left[\mathrm{PM}_{2.5}\right]$ is $17.5 \%$ on average, which is overwhelmingly dominated by enhanced SA. Model sensitivities also show that when the RH is less than $80 \%$, the ALW progressively increases near-surface $\left[\mathrm{PM}_{2.5}\right]$ but commences to decrease when the RH exceeds $80 \%$ due to the high occurrence frequencies of precipitation.

\section{Introduction}

Atmospheric aerosols or fine particle matter $\left(\mathrm{PM}_{2.5}\right)$ influences the climate directly by scattering and absorbing the solar radiation and indirectly by serving as cloud condensation nuclei and ice nuclei (Ackerman, 1977; Ackerman 
and Baker, 1977; Jacobson, 1998, 2002; Penner et al., 2001). Moreover, high levels of $\mathrm{PM}_{2.5}$ in the atmosphere also cause severe haze pollution, impairing visibility and exerting deleterious effects on the ecological system and human health (Chan and Yao, 2008; Zhang et al., 2013; Kurokawa et al., 2013; Weinhold, 2008; Parrish and Zhu, 2009). In addition to anthropogenic emissions, the poor air quality is generally influenced by stagnant meteorological situations with weak winds and high relative humidity (RH; Flocas et al., 2009; Quan et al., 2013; Zhang et al., 2014; Bei et al., 2016a, b; P. Wu et al., 2017; Ding et al., 2017). RH, as an important meteorological factor in the atmosphere, considerably affects the formation, chemical composition, and physical properties of atmospheric aerosols (Seinfeld et al., 2001; Hallquist et al., 2009; Poulain et al., 2010; Nguyen et al., 2011).

As the main constituent in the atmosphere, water vapor directly participates in the atmospheric physical and chemical processes. Since many components of atmospheric aerosols are hygroscopic, they take up water as RH increases (Covert et al., 1972; Pilinis et al., 1989), thereby influencing the aerosol size distribution, chemical composition, mass concentration, and corresponding optical properties as well as radiative effects (Im et al., 2001; Carrico et al., 2003; Randles et al., 2004; Cheng et al., 2008). Wang et al. (2016) indicated that the ratio of $\mathrm{SO}_{4}^{2-}$ to $\mathrm{SO}_{2}$ exhibits an exponential increase with RH. Tie et al. (2017) showed that the sulfate, nitrate, and ammonium concentrations increase from 16 to $25 \mu \mathrm{g} \mathrm{m}^{-3}, 15$ to $23 \mu \mathrm{g} \mathrm{m}^{-3}$, and 11 to $17 \mu \mathrm{g} \mathrm{m}^{-3}$, respectively, when RH increases from $60 \%$ to $80 \%$. Field measurements in Beijing have demonstrated that the inorganic aerosol fraction increases with increasing $\mathrm{RH}$ (Wu et al., 2018). In addition, water vapor also serves as an important medium in the formation of secondary aerosols (SA) through liquid-phase reactions and heterogeneous reactions (Seinfeld and Pandis, 1986; Pilinis et al., 1989). For example, Li et al. (2017) indicated that the aerosol liquid water (ALW) induced by the wet growth could play a significant role in the sulfate formation and emphasized the importance of bulk aqueous-phase oxidation of $\mathrm{SO}_{2}$ in ALW and heterogeneous reaction of $\mathrm{SO}_{2}$ on aerosol surfaces involving ALW. ALW also plays an important role in secondary organic aerosol (SOA) formation (Hastings et al., 2005; Healy et al., 2009; Kamens et al., 2011; Koehler et al., 2004). Numerous studies have investigated the effect of RH on SOA formed from different aromatics during their photochemical oxidation processes (Blando and Turpin, 2000; Cocker et al., 2001a, b, c; Seinfeld et al., 2001; Zhou et al., 2011; Jia and $\mathrm{Xu}, 2014)$. Furthermore, Zhang et al. (2015) revealed that, as the RH increases from $40 \%$ to $85 \%$ in the Yangtze River Delta of China, the aerosol scattering and backscattering coefficients increase by $58 \%$ and $25 \%$, respectively, and the calculated aerosol direct radiative forcing caused by hygroscopic growth increases by $47 \%$.

In recent years, China has experienced persistent haze pollution with unprecedentedly high $\mathrm{PM}_{2.5}$ concentrations dur- ing wintertime, particularly in the North China Plain (NCP; Chan and Yao, 2008; He et al., 2001; Kan et al., 2012; Guo et al., 2014; Wang et al., 2014; Fu et al., 2014). A conceptual model based on the aerosol-radiation feedback (ARF) has been established to interpret the wintertime heavy haze formation, in which water vapor is considered to play a key role in the progressive accumulation and formation of $\mathrm{PM}_{2.5}$. In winter, when the atmospheric condition is stagnant, air pollutants commence to accumulate in the planetary boundary layer (PBL), favorable for the $\mathrm{PM}_{2.5}$ formation. Increasing $\mathrm{PM}_{2.5}$ scatters or absorbs the incoming solar radiation to lower the surface temperature and cause anomalous temperature inversion, subsequently suppressing the vertical turbulent diffusion and decreasing the planetary boundary-layer height (PBLH) to further trap more air pollutants and water vapor to increase the $\mathrm{RH}$ in the PBL. Increasing $\mathrm{RH}$ enhances aerosol hygroscopic growth and multiphase reactions and augments the particle size and mass, causing further dimming and decrease in the surface temperature and PBLH (Quan et al., 2013; Tie et al., 2017; Ding et al., 2017). However, few studies have been performed in China to comprehensively quantify the effect of water vapor in the atmospheric physical and chemical process on the $\mathrm{PM}_{2.5}$ pollution to further verify the haze formation.

The purpose of the present study is to quantitatively evaluate the contribution of aerosol water induced by the aerosol wet growth to $\mathrm{PM}_{2.5}$ concentrations in the NCP using the Weather Research and Forecasting Model with Chemistry (WRF-Chem Model). The model configuration and methodology are described in Sect. 2. Results and discussions are presented in Sect. 3, and conclusions and summaries are given in Sect. 4.

\section{Model and methodology}

\subsection{WRF-Chem Model and configuration}

A persistent air pollution episode with high levels of $\mathrm{PM}_{2.5}$ from 5 December 2015 to 4 January 2016 in the NCP was simulated using the WRF-Chem Model with modifications by Li et al. (2010, 2011a, b, 2012) from the Molina Center for Energy and the Environment. Figure 1 shows the WRFChem Model simulation domain, and Table 1 provides the model configurations. A detailed model description can be found in Wu et al. (2019).

\subsection{Data and methodology}

The model performance of $\mathrm{RH}$ was validated using the hourly measurements in Luancheng, Yucheng, and Jiaozhouwan observed from the Chinese Ecosystem Research Network (CERN). Furthermore, the National Centers for Environmental Prediction (NCEP) reanalysis data were used to compare to the simulated RH distribution. The de- 


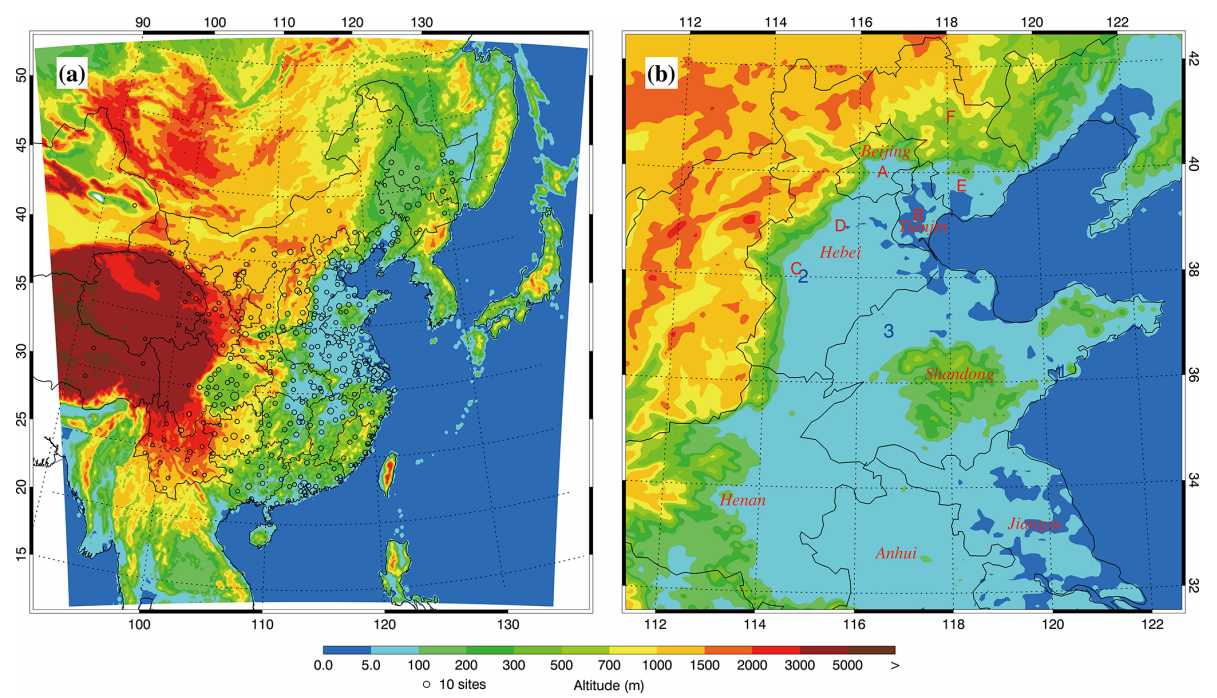

Figure 1. (a) WRF-Chem simulation domain with topography and (b) North China Plain. In (a), the blue circles represent centers of cities with ambient monitoring sites, and the size of circles denotes the number of ambient monitoring sites of cities. In (b), the red capitals denote six typical polluted cities in NCP: A is Beijing, B is Tianjin, C is Shijiazhuang, D is Baoding, E is Tangshan, and F is Chengde. The blue numbers denote the CERN sites with the hourly RH measurement: 1 is Jiaozhouwan, 2 is Yucheng, and 3 is Luancheng.

Table 1. WRF-Chem Model configurations.

\begin{tabular}{ll}
\hline Regions & East Asia \\
\hline Simulation period & 5 Dec 2015-4 Jan 2016 \\
Domain size & $400 \times 400$ \\
Domain center & $35^{\circ} \mathrm{N}, 114^{\circ} \mathrm{E}$ \\
Horizontal resolution & $12 \mathrm{~km} \times 12 \mathrm{~km}$ \\
Vertical resolution & $35 \mathrm{vertical}$ levels with a stretched vertical grid with spacing ranging \\
& from $30 \mathrm{~m}$ near the surface to 500 m at 2.5 km and $1 \mathrm{~km}$ above 14 km \\
Microphysics scheme & WSM 6-class graupel scheme (Hong and Lim, 2006) \\
Boundary-layer scheme & MYJ TKE scheme (Janjić, 2002) \\
Surface-layer scheme & MYJ surface scheme (Janjić, 2002) \\
Land-surface scheme & Unified Noah land-surface model (Chen and Dudhia, 2001) \\
Longwave radiation scheme & Goddard longwave scheme (Chou and Suarez, 2001) \\
Shortwave radiation scheme & Goddard shortwave scheme (Chou and Suarez, 1999) \\
Meteorological boundary and initial conditions & NCEP $1^{\circ} \times 1^{\circ}$ reanalysis data \\
Chemical initial and boundary conditions & MOZART 6h output (Horowitz et al., 2003) \\
Anthropogenic emission inventory & Developed by Zhang et al. (2009) and Li et al. (2017), \\
& 2012 base year, and SAPRC-99 chemical mechanism \\
Biogenic emission inventory & MEGAN model developed by Guenther et al. (2006) \\
Model spin-up time & 28h \\
\hline
\end{tabular}

tailed information of other data used for validation can be found in Wu et al. (2019).

The mean bias (MB), root-mean-square error (RMSE), and the index of agreement (IOA) were utilized to evaluate the performance of the WRF-Chem Model simulations against measurements. To assess the contributions of ALW to the near-surface concentrations of air pollutants in the NCP, the factor separation approach (FSA) was used in this study (Stein and Alpert, 1993; Gabusi et al., 2008; Li et al., 2014). Generally, the formation of the secondary atmospheric pol- lutants, such as $\mathrm{O}_{3}$, secondary organic aerosol, and nitrate, is a complicated nonlinear process in which its precursors from various emissions sources and transport react chemically or reach equilibrium thermodynamically. Nevertheless, it is not straightforward to evaluate the contributions from different factors in a nonlinear process (Wu et al., 2017). The FSA proposed by Stein and Alpert (1993) can be used to isolate the effect of one single factor from a nonlinear process and has been widely used to evaluate source effects. The total effect of one factor in the presence of others can be decomposed 

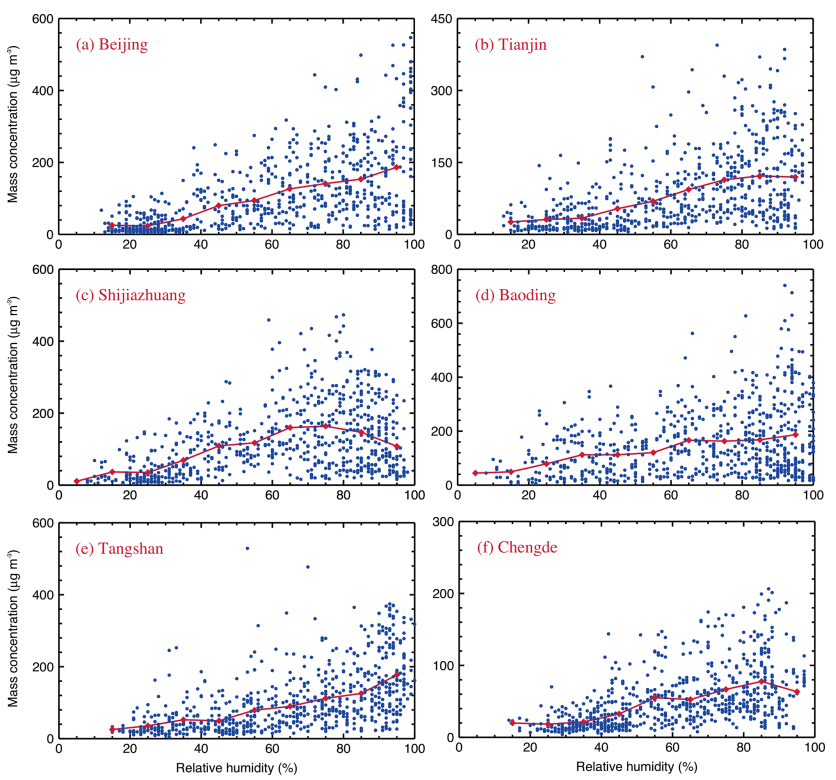

Figure 2. Scatter plots of near-surface $\left[\mathrm{PM}_{2.5}\right]$ and $\mathrm{RH}$ at six typical polluted cities in NCP during the 2015 wintertime. The red diamond shows the bin average of near-surface $\left[\mathrm{PM}_{2.5}\right]$, and the red line denotes the variation in the bin average of near-surface $\left[\mathrm{PM}_{2.5}\right]$ with RH.

into contributions from the factor and that from the interactions of all those factors, considering that there are two factors $X$ and $Y$ that influence the formation of secondary pollutants in the atmosphere and also interact with each other. We denote $f_{X Y}, f_{X}, f_{Y}$, and $f_{0}$ as the simulations including both of two factors, factor $X$ only, factor $Y$ only, and none of the two factors, respectively. The contributions of factor $X$ and $Y$ can be defined as $f_{X Y}-f_{Y}$ and $f_{X Y}-f_{X}$, respectively. A detailed description of the methodology can be found in $\mathrm{Wu}$ et al. (2017).

\section{Results and discussions}

\subsection{Relationship between $\mathrm{RH}$ and near-surface $\mathbf{P M}_{2.5}$ concentrations}

High RH has been suggested to be an important factor facilitating the SA formation in the atmosphere and aggravating the haze pollution (Sun et al., 2013; Cheng et al., 2015). Figure 2 presents the scatter plot of the near-surface $\mathrm{PM}_{2.5}$ concentrations $\left(\left[\mathrm{PM}_{2.5}\right]\right)$ and $\mathrm{RH}$ in the winter of 2015 at six typical polluted cities in the NCP, including Beijing, Tianjin, Shijiazhuang, Tangshan, Baoding, and Chengde. The observed near-surface $\left[\mathrm{PM}_{2.5}\right]$ at those six cities displays a growing trend with increasing RH, suggesting that the ALW induced by the hygroscopic growth under high RH conditions has the potential to accelerate the $\mathrm{PM}_{2.5}$ formation and accumulation. Increasing RH facilitates the aerosol hygroscopic growth and further enhances the ALW, serving as an

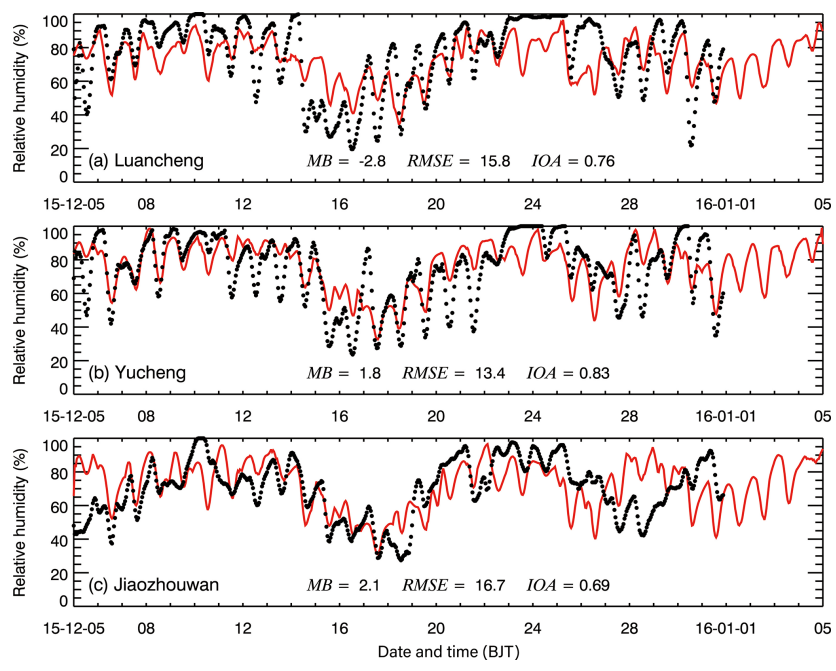

Figure 3. Comparison of measured (black dots) and predicted (red line) diurnal profiles of the RH in (a) Luancheng, (b) Yucheng, and (c) Jiaozhouwan from 5 December 2015 to 4 January 2016.

efficient medium for promoting the liquid-phase and heterogeneous reactions and accelerating the transformation of reactive gaseous pollutants into the particle phase. Increased ALW also augments the particle size, enhancing the ARF to increase the near-surface $\left[\mathrm{PM}_{2.5}\right]$. However, the attenuation of incoming solar radiation caused by the ALW also decreases the photolysis rates, being unfavorable for photochemical activities and lowering the atmospheric oxidation capability (AOC). Field measurements show that a large fraction of SA in $\mathrm{PM}_{2.5}$ has been observed in the NCP during wintertime (Sun et al., 2013; Guo et al., 2014; Xu et al., 2015). Therefore, decreased AOC generally does not facilitate the SA formation, particularly with regards to SOA and nitrate, to partially counteract the $\mathrm{PM}_{2.5}$ enhancement caused by the ALW. It is also worth noting that since high RH frequently corresponds to atmospheric stagnation, near-surface $\left[\mathrm{PM}_{2.5}\right]$ also builds up under high RH conditions. For example, the humid air mass is subject to being transported from the south to the NCP under the stagnant weather with weak south winds, and meanwhile the $\mathrm{PM}_{2.5}$ also accumulates due to the unfavorable dispersion condition. Additionally, when the $\mathrm{RH}$ is very high, the low near-surface $\left[\mathrm{PM}_{2.5}\right]$ also exists and is shown in Fig. 2, demonstrating that other factors, such as emissions, horizontal transport, vertical exchange, and precipitation, also substantially influence near-surface $\left[\mathrm{PM}_{2.5}\right]$. Generally, high occurrence frequency of precipitation coincides with high $\mathrm{RH}$; thus the precipitation washout might constitute one of the most possible reasons for the low near-surface $\left[\mathrm{PM}_{2.5}\right]$ under high RH situations. Therefore, it is still imperative to verify quantitatively the contribution of the ALW to near-surface $\left[\mathrm{PM}_{2.5}\right]$. 
Table 2. Description of the sensitivity simulations.

\begin{tabular}{|c|c|c|c|c|}
\hline \multirow[t]{2}{*}{ Case } & \multirow{2}{*}{$\begin{array}{c}\text { Aerosol } \\
\text { hygroscopic } \\
\text { growth }\end{array}$} & \multicolumn{2}{|c|}{ ALW contribution to AOD } & \multirow{2}{*}{$\begin{array}{c}\text { Multiphase } \\
\text { reactions involving } \\
\text { the ALW }\end{array}$} \\
\hline & & in the ARF & in the photolysis & \\
\hline$f_{\text {base }}$ & On & On & On & On \\
\hline$f_{\text {alw_rad0 }}$ & On & Off & On & On \\
\hline$f_{\mathrm{alw} \_\mathrm{j} 0}$ & On & On & Off & On \\
\hline$f_{\text {alw_het0 }}$ & On & On & On & Off \\
\hline$f_{\text {alw_tot0 }}$ & On & Off & Off & Off \\
\hline
\end{tabular}

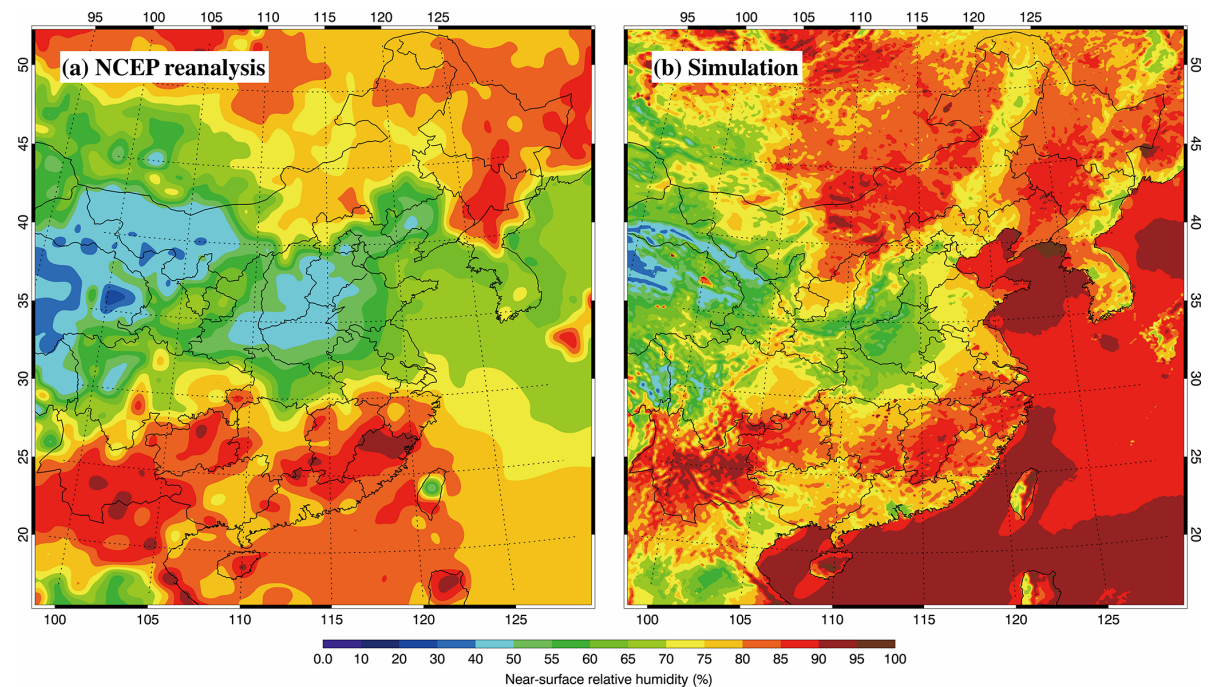

Figure 4. Spatial distribution of (a) NCEP reanalysis and (b) simulated RH averaged from 5 December 2015 to 4 January 2016.

\subsection{Model validation}

The WRF-Chem Model simulation of the haze pollution episode in the NCP has been comprehensively validated using available measurements in Wu et al. (2019). In general, the model simulates the spatial distribution and temporal variation in $\mathrm{PM}_{2.5}, \mathrm{O}_{3}, \mathrm{NO}_{2}, \mathrm{SO}_{2}$, and $\mathrm{CO}$ mass concentrations well compared to observations in the NCP. The predicted aerosol species are also in good agreement with the measurement in Beijing. Moreover, the model performs reasonably well in simulating the aerosol optical depth and single scattering albedo, PBLH, and downward shortwave flux against measurements.

In order to verify the effect of the ALW on near-surface $\left[\mathrm{PM}_{2.5}\right]$ during the haze pollution episode, the simulated temporal variation in RH was first compared to measurements at Luancheng, Yucheng, and Jiaozhouwan in the NCP from 5 December 2015 to 4 January 2016 (Fig. 3). The WRF-Chem Model generally performs well in simulating the hourly variation in RH in these three cities, with IOAs of $0.73,0.83$, and 0.69 , respectively. $\mathrm{RH}$ is a key meteorological component, sensitive to the atmospheric thermodynamic (e.g., temperature) and dynamic (e.g., winds) condi- tions. Even when the simulated water vapor content is the same as the observation, the overestimation or underestimation of temperature still causes underestimation or overestimation of RH. Biases of wind speeds and directions considerably influence the origination of air mass at the observation site. In general, the northerly wind carries dry air, and this is the opposite for the southerly wind during wintertime in the NCP. Therefore, the uncertainties from meteorological field simulations might constitute one of the most possible reasons for the RH bias (Bei et al., 2017). Figure 4 presents the pattern comparison of the average simulated $\mathrm{RH}$ and the NCEP reanalysis during the episode. The simulated RH distribution is generally consistent with that from the reanalysis, e.g., dry air in western China and fairly humid air in southern China. However, the air over the NCP in the simulation is more humid than the analysis, and the average simulated $\mathrm{RH}$ is $70.6 \%$, about $20 \%$ higher than the reanalyzed $\mathrm{RH}$, which might be caused by the temperature decrease due to the ARF considered in the simulation. 

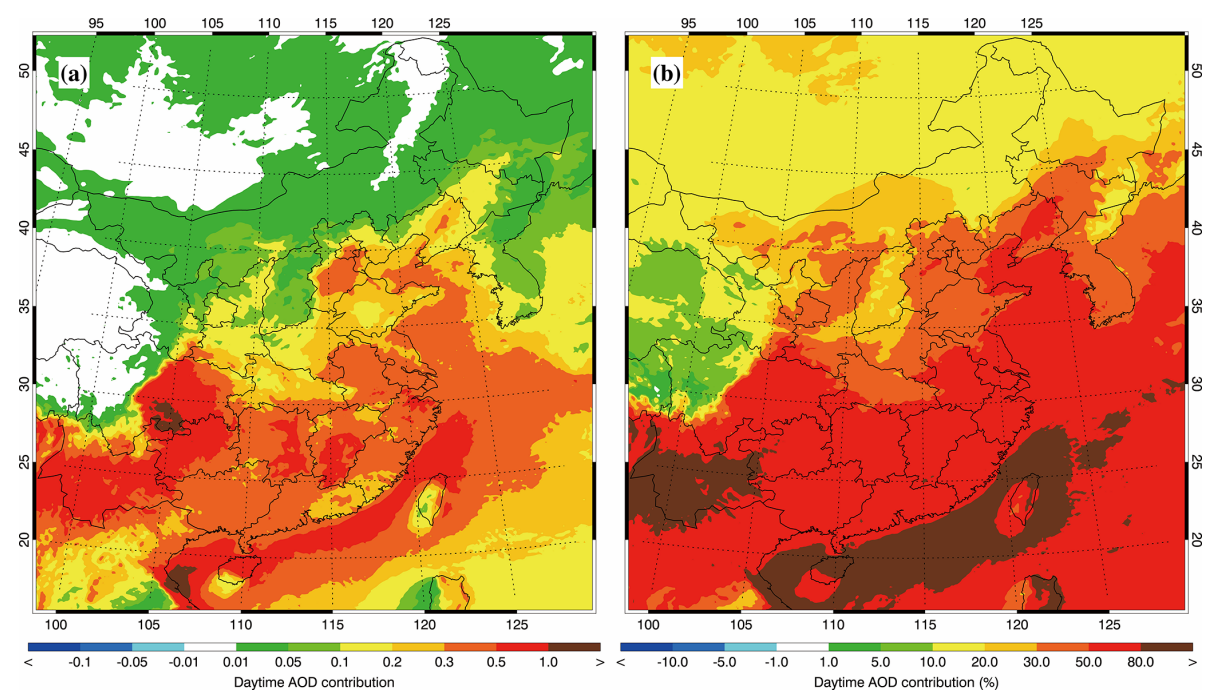

Figure 5. Average (a) absolute and (b) relative AOD contribution caused by the ALW from 5 December 2015 to 4 January 2016.
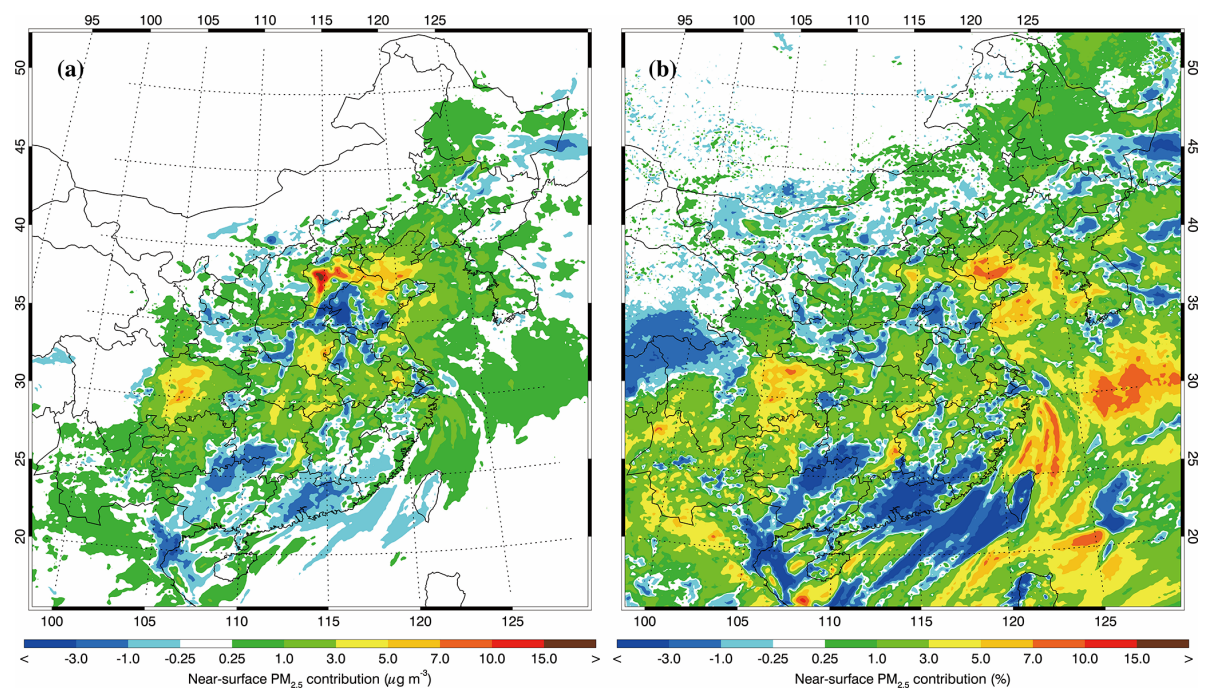

Figure 6. Average near-surface (a) absolute and (b) relative $\mathrm{PM}_{2.5}$ contribution caused by the ALW-ARF from 5 December 2015 to 4 January 2016.

\subsection{Sensitivity studies}

The ALW not only enlarges the particle size to increase the aerosol optical depth (AOD), likely enhancing the ARF to facilitate the $\mathrm{PM}_{2.5}$ accumulation or to alter photolysis rates to affect the AOC, but also influences the SA formation serving as a medium for multiphase reactions. Therefore, sensitivity studies are used to quantitatively evaluate the effect of the ALW on the $\mathrm{PM}_{2.5}$ concentration during the haze pollution episode.

The FSA method was used to evaluate the contribution of the ALW to near-surface $\left[\mathrm{PM}_{2.5}\right]$ by differentiating two model simulations with and without the ALW effect. Besides the base case with all the ALW effect (hereafter referred to as $f_{\text {base }}$ ), additionally, four sensitivity simulations have been performed in which the ALW effect on the ARF, photolysis, multiphase reactions, and the total is excluded, respectively (hereafter referred to as $f_{\text {alw_rad0 } 0}, f_{\text {alw_j } 0}, f_{\text {alw_het } 0 \text {, and }}$ $f_{\text {alw_tot0 }}$, respectively). It is worth noting that in all the sensitivity simulations, the aerosol hygroscopic growth is not turned off. In the sensitivity simulation $f_{\text {alw_rad0, only the }}$ ALW contribution to the AOD is not included in the ARF. In the $f_{\mathrm{alw} \_\mathrm{j} 0}$, only the ALW contribution to the AOD is not considered in the photolysis calculation. In the $f_{\text {alw_het } 0}$, only the heterogeneous formation of secondary aerosols (SA) involving the ALW is turned off, including the $\mathrm{SO}_{2}$ heterogeneous oxidation by $\mathrm{O}_{2}$ catalyzed by $\mathrm{Fe}^{3+}, \mathrm{N}_{2} \mathrm{O}_{5}$ heterogeneous hydrolysis, and the heterogeneous reaction of glyoxal 

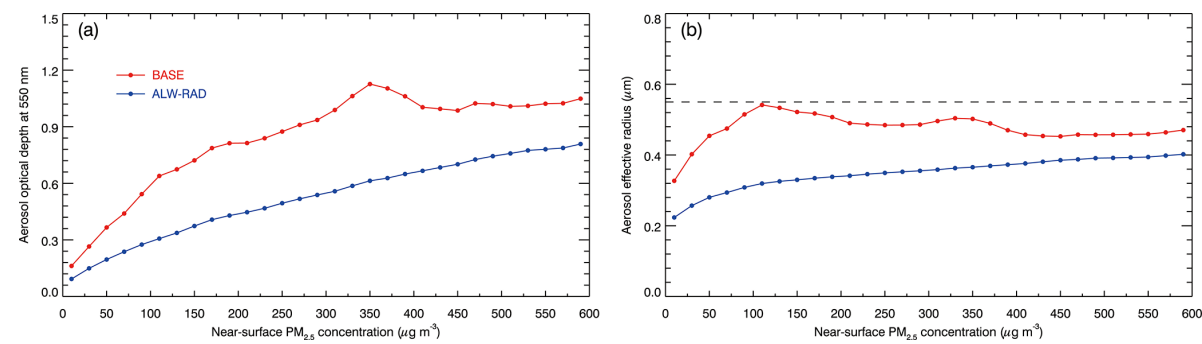

Figure 7. Average variations in (a) AOD and (b) Reff in $f_{\text {base }}$ (red line) and $f_{\text {alw_rad0 }}$ (blue line) as a function of bin [PM 2.5$]$ in NCP during daytime from 5 December 2015 to 4 January 2016.
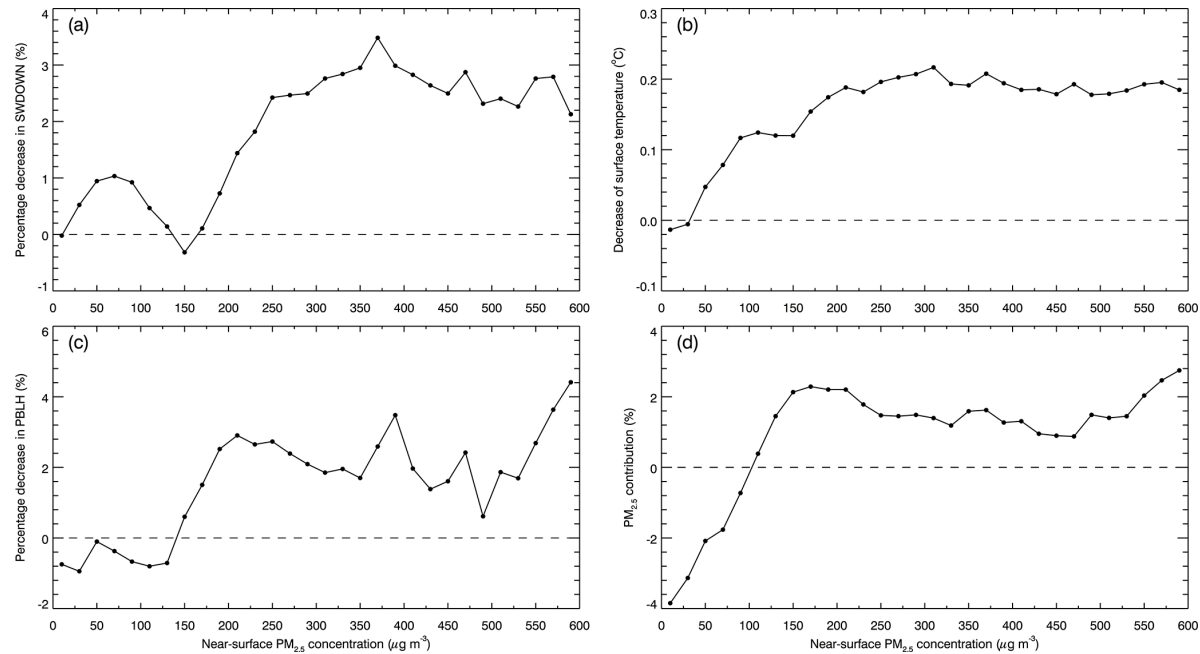

Figure 8. Average (a) percentage decrease in SWDOWN at the ground surface, (b) decrease in TSFC, (c) percentage decrease in PBLH, and (d) percentage contribution of near-surface $\left[\mathrm{PM}_{2.5}\right]$ caused by the ALW-ARF as a function of the near-surface [PM 2.5$]$ in NCP during daytime from 5 December 2015 to 4 January 2016.

and methylglyoxal. For the $f_{\text {alw_toto }}$, the ALW contribution to the AOD is not considered in the ARF and photolysis calculation, and the SA heterogeneous formation involving the ALW is excluded. A detailed description about the sensitivity simulations can be found in Table 2. The difference between $f_{\text {base }}$ and $f_{\text {alw_rad0 }}$ represents the ALW effect on the ARF during the study episode, and so does for the ALW effect on photochemistry, multiphase reactions, and the total ALW effect.

\subsubsection{ALW effect on the ARF}

The ALW, caused by the aerosol hygroscopic growth, augments the particle size to increase AOD, potentially enhancing the ARF and aggravating the haze pollution. Figure 5 shows the distribution of the average AOD contribution due to the ALW during the haze episode, evaluated by differentiating $f_{\text {base }}$ and $f_{\text {alw_rado } 0}$. Apparently, the ALW substantially increases the $\mathrm{AOD}$ in the $\mathrm{NCP}$, with the contribution ranging from $30 \%$ to more than $50 \%$, indicating that ALW is an important contributor of the AOD. Substantial increase in the AOD due to the ALW is anticipated to attenuate the incom- ing solar radiation, decreasing the surface temperature and suppressing the PBL development and therefore deteriorating the haze pollution, as proposed by recent studies (Tie et al., 2017; Liu et al., 2018).

Figure 6 presents the distribution of the average nearsurface $\mathrm{PM}_{2.5}$ contribution of the ALW effect on the ARF (hereafter referred as to ALW-ARF) during the haze episode. Interestingly, the ALW-ARF does not increase the nearsurface $\left[\mathrm{PM}_{2.5}\right]$ consistently in the NCP, as expected. The ALW-ARF enhances the near-surface $\left[\mathrm{PM}_{2.5}\right]$ most strikingly in the south of Hebei, with a contribution of more than $15 \mathrm{\mu g} \mathrm{m}^{-3}$ (less than $7 \%$ ). However, in some areas, such as the east of Shandong, the near-surface $\mathrm{PM}_{2.5}$ contribution of the ALW-ARF is negative or the ALW-ARF decreases $\left[\mathrm{PM}_{2.5}\right]$. On average, the ALW-ARF increases near-surface $\left[\mathrm{PM}_{2.5}\right]$ in the NCP during the episode by about $1.1 \mu \mathrm{g} \mathrm{m}^{-3}$, so it cannot constitute an important factor for the heavy haze formation.

It is worth noting that enlarged particles due to the ALW not only increase the AOD to enhance aerosol backward scattering but also cause the aerosol spectrum to successively 

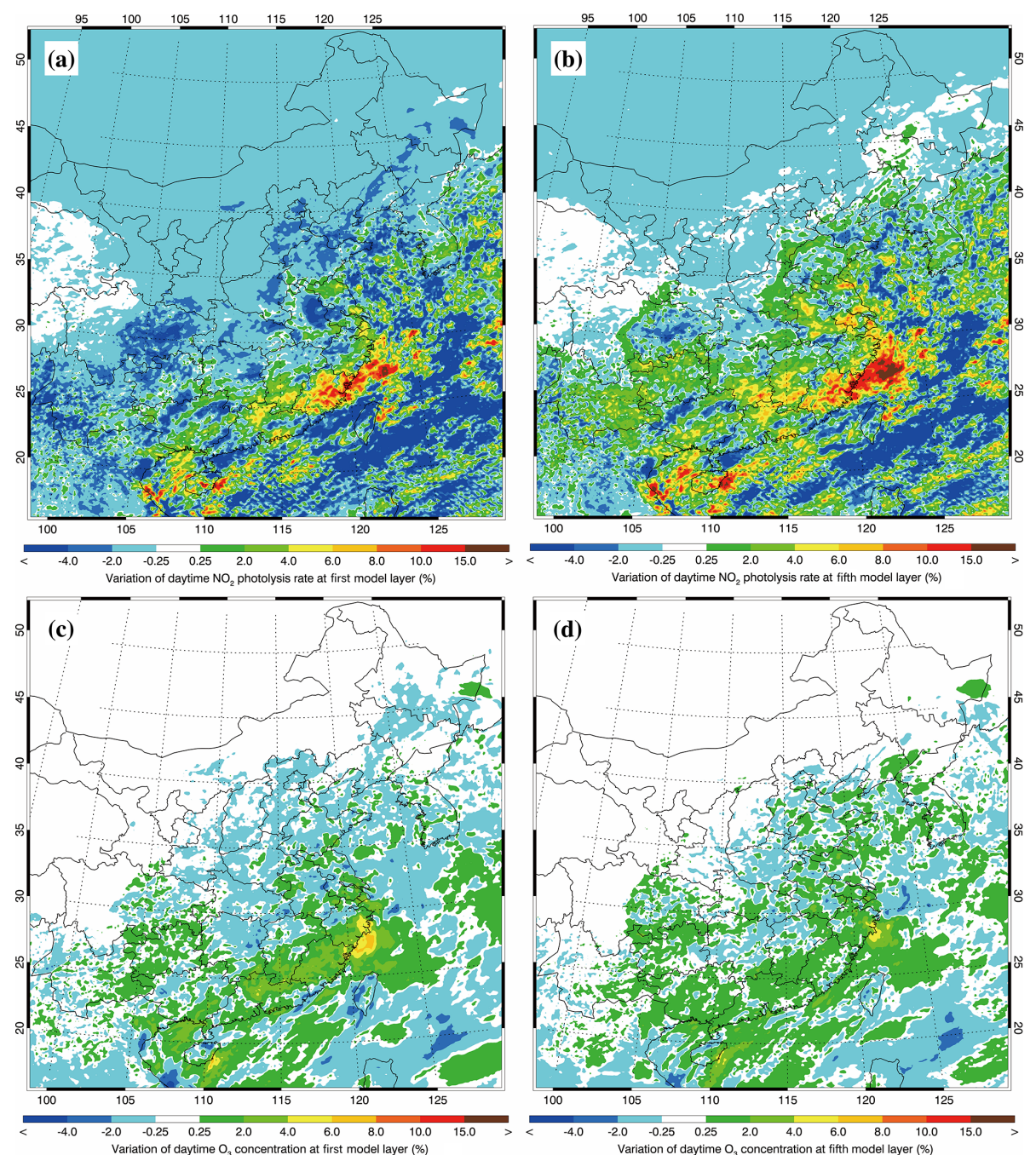

Figure 9. Average variations in daytime (a), (b) $\mathrm{NO}_{2}$ photolysis at the first and fifth model layer, respectively, and (c),(d) $\mathrm{O}_{3}$ concentration at first and fifth model layer at around 18 and $420 \mathrm{~m}$ above the ground surface, respectively, caused by the ALW from 5 December 2015 to 4 January 2016 in NCP.

shift toward larger sizes. Based on the Mie scattering theory, when the particle size is similar to the wavelength of incoming solar radiation, the radiation is favored to be scattered in the forward directions. In order to further verify the ALW effect on solar radiation and near-surface $\left[\mathrm{PM}_{2.5}\right]$, an ensemble method is employed similar to that reported in $\mathrm{Wu}$ et al. (2019). The daytime near-surface $\left[\mathrm{PM}_{2.5}\right]$ in the NCP during the episode in $f_{\text {base }}$ is first subdivided into 30 bins with the interval of $20 \mu \mathrm{g} \mathrm{m}^{-3}$. The AOD at $550 \mathrm{~nm}$, aerosol effective radius (Reff), downward shortwave radiation at the surface (SWDOWN), surface temperature (TSFC), PBLH, and near-surface $\left[\mathrm{PM}_{2.5}\right]$ in $f_{\text {base }}$ and $f_{\text {alw_rado }}$ in the same grid cell are assembled as the bin $\left[\mathrm{PM}_{2.5}\right]$, and an average of these variables in each bin are calculated. Figure 7 shows the variation in AOD and Reff in $f_{\text {base }}$ and $f_{\text {alw_rad0 }}$ as a function of bin $\left[\mathrm{PM}_{2.5}\right]$. The ALW not only significantly enhances the AOD, with an average contribution of $46 \%$ in the
NCP during the episode but also increases the Reff considerably (Fig. 7a and b). The Reff enhancement due to the ALW is the most striking with near-surface $\left[\mathrm{PM}_{2.5}\right]$ between 40 and $160 \mu \mathrm{g} \mathrm{m}^{-3}$, exceeding $60 \%$. On average, the ALW increases the Reff from $0.31 \mu \mathrm{m}$ to $0.48 \mu \mathrm{m}$, close to the peak band of solar radiation. Therefore, the ALW increases the AOD to scatter more incoming solar radiation, decreasing the SWDOWN, but augments particle sizes to favor the forward scattering, increasing the SWDOWN. Generally, the decrease in the SWDOWN caused by the ALW is not significant, being less than $1 \%$ with near-surface $\left[\mathrm{PM}_{2.5}\right]$ of less than $200 \mu \mathrm{g} \mathrm{m}^{-3}$ and ranging from $2 \%$ to $3 \%$ with $\left[\mathrm{PM}_{2.5}\right]$ exceeding $240 \mu \mathrm{g} \mathrm{m}^{-3}$ (Fig. 8a). Correspondingly, the ALWARF effect on the daytime TSFC is also marginal and the TSFC is decreased by less than $0.2{ }^{\circ} \mathrm{C}$ (Fig. 8b). Furthermore, the ALW-ARF generally increases the daytime PBLH with near-surface $\left[\mathrm{PM}_{2.5}\right]$ less than $140 \mu \mathrm{g} \mathrm{m}^{-3}$ but is op- 

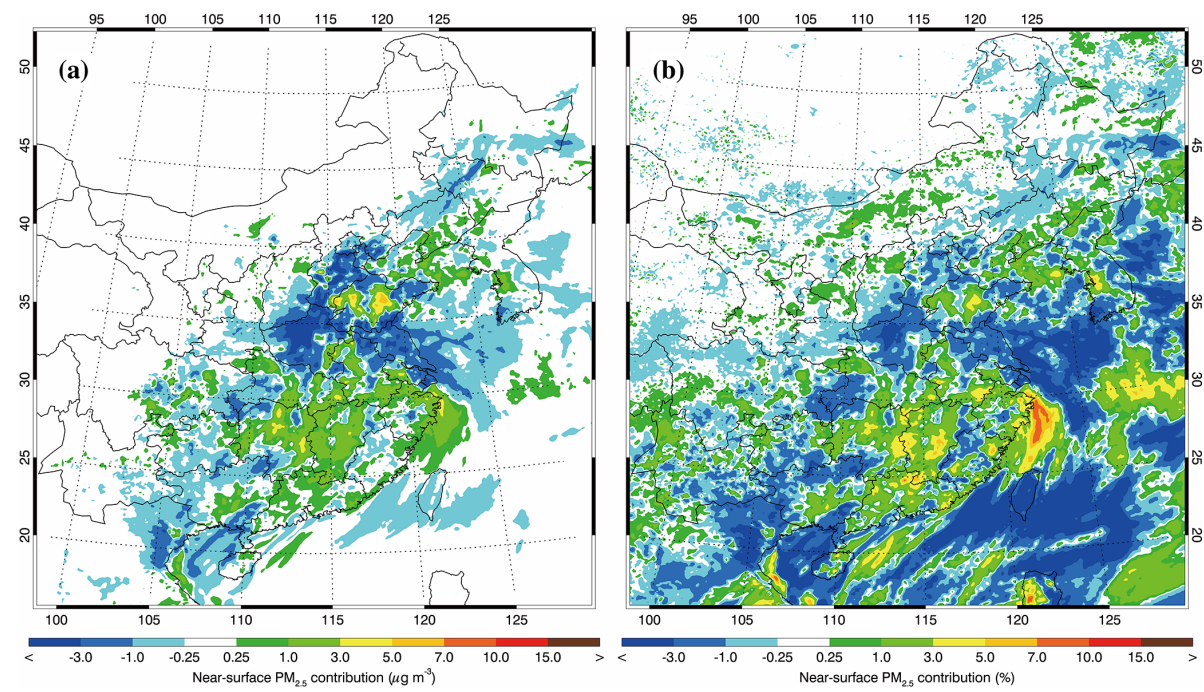

Figure 10. Average near-surface (a) absolute and (b) relative $\mathrm{PM}_{2.5}$ contribution caused by the ALW-J from 5 December 2015 to 4 January 2016.

posite with $\left[\mathrm{PM}_{2.5}\right]$ exceeding $140 \mu \mathrm{g} \mathrm{m}^{-3}$ (Fig. 8c). Hence, the contribution of the ALW-ARF to near-surface $\left[\mathrm{PM}_{2.5}\right]$ is highly uncertain (Fig. 8d), depending on the relative importance of the ALW induced enhancement of aerosol backward and forward scattering.

\subsubsection{ALW effect on the photochemistry}

In addition to the ARF, the ALW also exerts an impact on the photochemistry by altering the aerosol backward and forward scattering to affect the photolysis, further influencing the ozone $\left(\mathrm{O}_{3}\right)$ and SA formation. Previous studies have shown that the ALW modifies the vertical profile of photolysis rate of $\mathrm{NO}_{2}\left(J_{\mathrm{NO}_{2}}\right)$, inhibiting it at the ground level and accelerating it in the upper PBL (Tao et al., 2014; Dickerson et al., 1997). The combination reaction between the ground-state oxygen atom $\left(\mathrm{O}^{3} \mathrm{P}\right)$, produced from $\mathrm{NO}_{2}$ photolysis, and oxygen molecules $\left(\mathrm{O}_{2}\right)$ forms $\mathrm{O}_{3}$, representing the only important source of $\mathrm{O}_{3}$ in the troposphere:

$\mathrm{NO}_{2}+h v \rightarrow \mathrm{NO}+\mathrm{O}\left({ }^{3} \mathrm{P}\right)$,

$\mathrm{O}\left({ }^{3} \mathrm{P}\right)+\mathrm{O}_{2}+M \rightarrow \mathrm{O}_{3}+M$.

Thus, the variation in $J_{\mathrm{NO}_{2}}$ considerably affects the $\mathrm{O}_{3}$ formation in the troposphere, changing the $\mathrm{AOC}$ and, further, the SA formation.

Figure $9 \mathrm{a}$ and $\mathrm{b}$ present the distribution of the percentage variation in average daytime $J_{\mathrm{NO}_{2}}$ due to the ALW during the haze episode at the first and fifth model layer, respectively. At the first model layer, except in the north of Jiangsu, the ALW generally decreases $J_{\mathrm{NO}_{2}}$ slightly in the NCP. However, at the fifth model layer, the region with enhanced $J_{\mathrm{NO}_{2}}$ caused by the ALW is obviously increased compared to that at the first model layer. Apparently, the ALW induced enlargement of particle sizes increases the AOD and enhances the aerosol backward scattering to reduce the solar radiation reaching the ground level, decreasing the photolysis rate, but the enhanced forward scattering still potentially accelerates the photolysis, such as in the north of Jiangsu. In addition, the enhanced aerosol backward scattering also increases the photolysis rate in the upper layer and above the PBL, which is consistent with previous studies (Tao et al., 2014; Dickerson et al., 1997). The variation in average daytime $\mathrm{O}_{3}$ concentrations is not consistent with that of $J_{\mathrm{NO}_{2}}$ at the first model layer (Fig. 9c). For example, although the $J_{\mathrm{NO}_{2}}$ is decreased in Hebei and Shandong, the $\mathrm{O}_{3}$ concentration is still enhanced by the ALW in some areas of the two provinces. One of the possible reasons is the vertical transport of $\mathrm{O}_{3}$ from the upper layers where the $\mathrm{O}_{3}$ is plausibly enhanced due to the increased photolysis rate (Fig. 9b). At the fifth model layer, the area with enhanced $\mathrm{O}_{3}$ concentrations is much larger than that at the first model layer, which is in agreement with the variation in the $J_{\mathrm{NO}_{2}}$ (Fig. 9d). On average, the ALW decreases near-surface (first model layer) daytime $\mathrm{O}_{3}$ concentrations by about $0.2 \mu \mathrm{g} \mathrm{m}^{-3}$ (or $0.45 \%$ ), playing a minor role in $\mathrm{O}_{3}$ formation.

Figure 10 shows the distribution of the average nearsurface $\mathrm{PM}_{2.5}$ contribution of the ALW effect on the photolysis frequencies (hereafter referred as to ALW-J) during the haze episode. Except in some areas in Shandong and Anhui, the ALW-J slightly decreases near-surface $\left[\mathrm{PM}_{2.5}\right]$ in the $\mathrm{NCP}$, with an average reduction of about $0.87 \mu \mathrm{g} \mathrm{m}^{-3}$ (or $0.64 \%$ ). Therefore, the ALW-J does not play an important role in mitigating the haze pollution. 

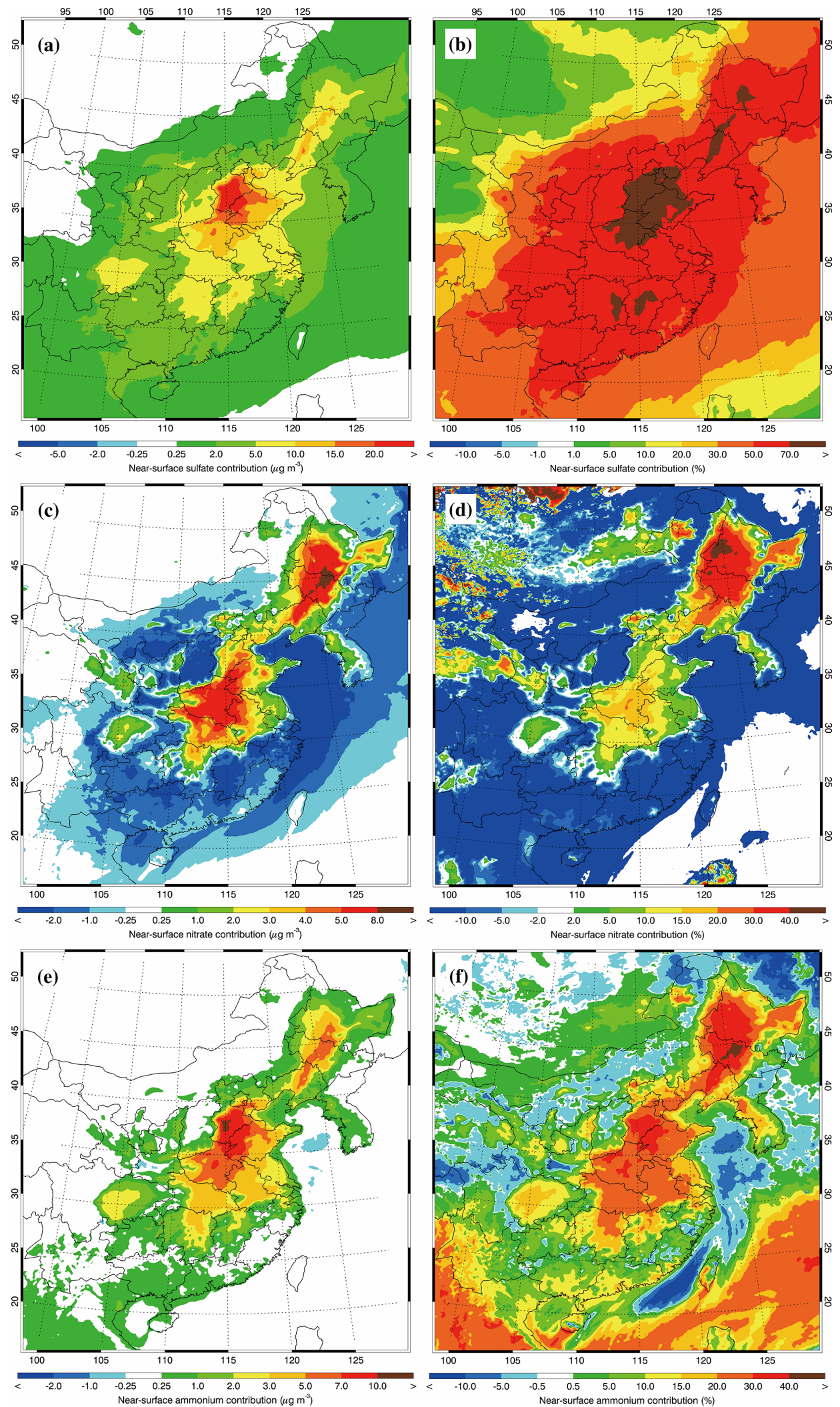

Figure 11. Average near-surface (a, c, e) absolute and (b, d, f) relative contribution to sulfate, nitrate, and ammonium concentrations, respectively, caused by the ALW-HET from 5 December 2015 to 4 January 2016. 


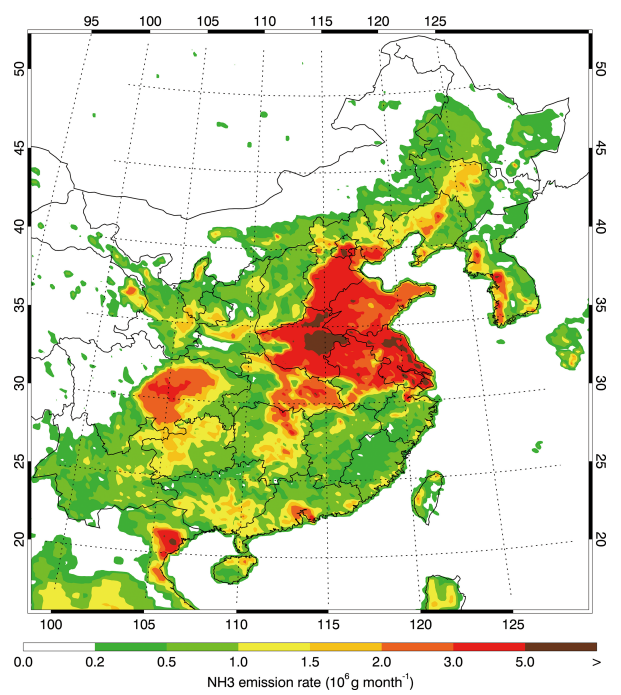

Figure 12. Spatial distribution of $\mathrm{NH}_{3}$ emission rate in December.

\subsubsection{ALW effect on heterogeneous reactions}

The ALW provides an excellent substrate for heterogeneous reactions in the atmosphere, which has been proposed to play a key role in the SA formation during haze days ( $\mathrm{Li}$ et al., 2017; Xing et al., 2019).

Figure 11 presents the distribution of contributions of the ALW on heterogeneous reactions (hereafter referred to ALW-HET) to near-surface sulfate, nitrate, and ammonium concentrations averaged during the haze episode. A parameterization of sulfate heterogeneous formation involving ALW has been developed and implemented into the WRFChem Model, which has successfully reproduced the observed rapid sulfate formation during haze days ( $\mathrm{Li}$ et al., 2017). The sulfate heterogeneous formation from $\mathrm{SO}_{2}$ is parameterized as a first-order irreversible uptake by ALW surfaces, with a reactive uptake coefficient of $0.5 \times 10^{-4}$, assuming that there is enough alkalinity to maintain the high iron-catalyzed reaction rate. The contribution of the ALWHET to the sulfate formation is substantial in the NCP, exceeding $5 \mu \mathrm{g} \mathrm{m}^{-3}$ (or $50 \%$ ) in the NCP (Fig. 11a and b). The ALW-HET contributes about $71.3 \%$ of the sulfate in the NCP during the episode, indicating that the heterogeneous formation involving the ALW is the dominant sulfate source during haze days.

The heterogeneous hydrolysis of $\mathrm{N}_{2} \mathrm{O}_{5}$ on the surface of deliquescent aerosols leads to the $\mathrm{HNO}_{3}$ formation, which is the key contributor to the nitrate aerosol loading (Riemer et al., 2003; Pathak et al., 2011; Chang et al., 2016). In this study, the parameterization of the heterogeneous hydrolysis of $\mathrm{N}_{2} \mathrm{O}_{5}$, proposed by Riemer et al. (2003), has been included in the WRF-Chem Model for considering the effect of ALWHET on the nitrate formation. The $\mathrm{N}_{2} \mathrm{O}_{5}$ uptake coefficient on wet aerosol surfaces ranges from 0.002 to 0.02 , depending on the sulfate and nitrate aerosol mass. The ALW-HET generally increases the near-surface nitrate mass concentration by 2 to $8 \mu \mathrm{g} \mathrm{m}^{-3}$ in the $\mathrm{NCP}$, with an average contribution of $2.8 \mu^{-3} \mathrm{~m}^{-3}$ (or $10 \%$; Fig. $11 \mathrm{c}$ and d). It is worth noting that the ALW-HET does not consistently increase the nitrate formation and that the nitrate concentration is considerably decreased in some areas in eastern China. One of the possible reasons is that the ALW-HET substantially enhances the sulfate formation and the increased sulfate competes with nitrate for ammonia $\left(\mathrm{NH}_{3}\right)$, suppressing the nitrate formation. Figure 12 shows the distribution of the $\mathrm{NH}_{3}$ emission rate in December. High $\mathrm{NH}_{3}$ emissions are concentrated in the NCP, central China, the Sichuan Basin, and northeastern China, where the nitrate concentration is generally increased by the ALW-HET.

Ammonium serves as the main alkali in the atmosphere to neutralize acidic aerosols such as sulfate and nitrate, so its formation is not only dependent on its precursor $\left(\mathrm{NH}_{3}\right)$ but is also influenced by acid aerosols. The ALW-HET enhances the near-surface ammonium mass concentration most strikingly in the $\mathrm{NCP}$ with high $\mathrm{NH}_{3}$ emissions and increased sulfate and nitrate aerosols. The contribution of the ALWHET to the ammonium concentration varies from 2 to more than $10 \mu \mathrm{g} \mathrm{m}^{-3}$, with an average of $4.2 \mu \mathrm{g} \mathrm{m}^{-3}$ (or $25.6 \%$ ), showing that the heterogeneous formation constitutes an important ammonium source (Fig. 11e and f).

Heterogeneous reactions are also an important pathway for the SOA formation (Fu et al., 2008; Li et al., 2013). Laboratory and field studies have indicated that glyoxal and methylglyoxal play an important role in SOA formation via aerosol uptake or cloud processing (Liggio et al., 2005; Volkamer et al., 2007; Li et al., 2011a). In this study, the heterogeneous reaction of SOA formation from glyoxal and methylglyoxal is parameterized as a first-order irreversible uptake by aerosol particles, with a reaction uptake coefficient of $3.7 \times 10^{-3}$ (Liggio et al., 2005; Zhao et al., 2006; Volkamer et al., 2007; Li et al., 2011). During the haze episode, the average nearsurface SOA contribution of the ALW-HET is $7.4 \mu \mathrm{g} \mathrm{m}^{-3}$ (or $48 \%$ ) in the NCP, ranging from 3 to over $15 \mu \mathrm{g} \mathrm{m}^{-3}$ (or 30 to over $50 \%$ ) in the NCP, showing that heterogeneous reactions of glyoxal and methylglyoxal on wet aerosol surfaces play a critical role in SOA formation (Fig. 13). Xing et al. (2019) demonstrated that, in Beijing-Tianjin-Hebei, the near-surface SOA contribution from glyoxal and methylglyoxal is around $30 \%$ during a haze episode in January 2014, much less than that (48\%) in the study. The possible reason is that the RH in the episode is higher than that in Xing et al. (2019), causing more SOA formation from glyoxal and methylglyoxal.

High SA contribution to the haze pollution has been observed in China (e.g., Huang et al., 2014), so the ALW-HET substantially enhances the SA formation, constituting an important factor for heavy haze formation. Figure 14 shows the contribution of the ALW-HET to average near-surface $\left[\mathrm{PM}_{2.5}\right]$ during the study episode. The ALW-HET enhances near-surface $\left[\mathrm{PM}_{2.5}\right]$ by more than $40 \mu \mathrm{g} \mathrm{m}^{-3}$ in the central 

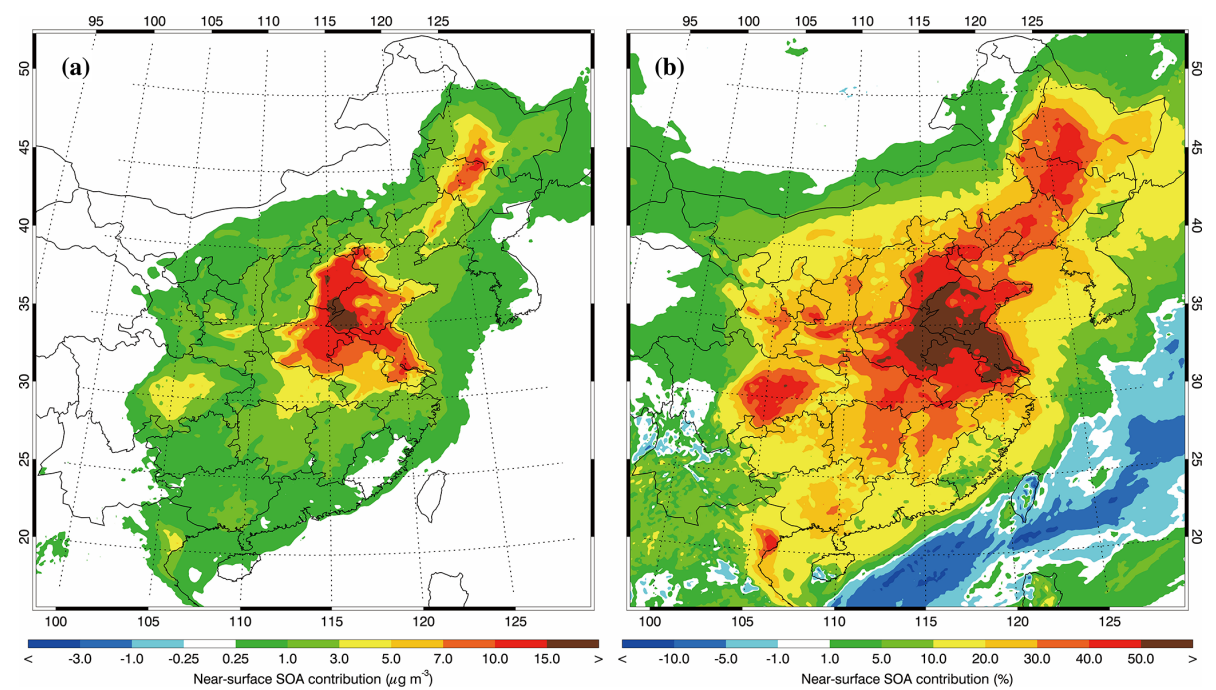

Figure 13. Average near-surface (a) absolute and (b) relative SOA contribution caused by the ALW-HET from 5 December 2015 to 4 January 2016.
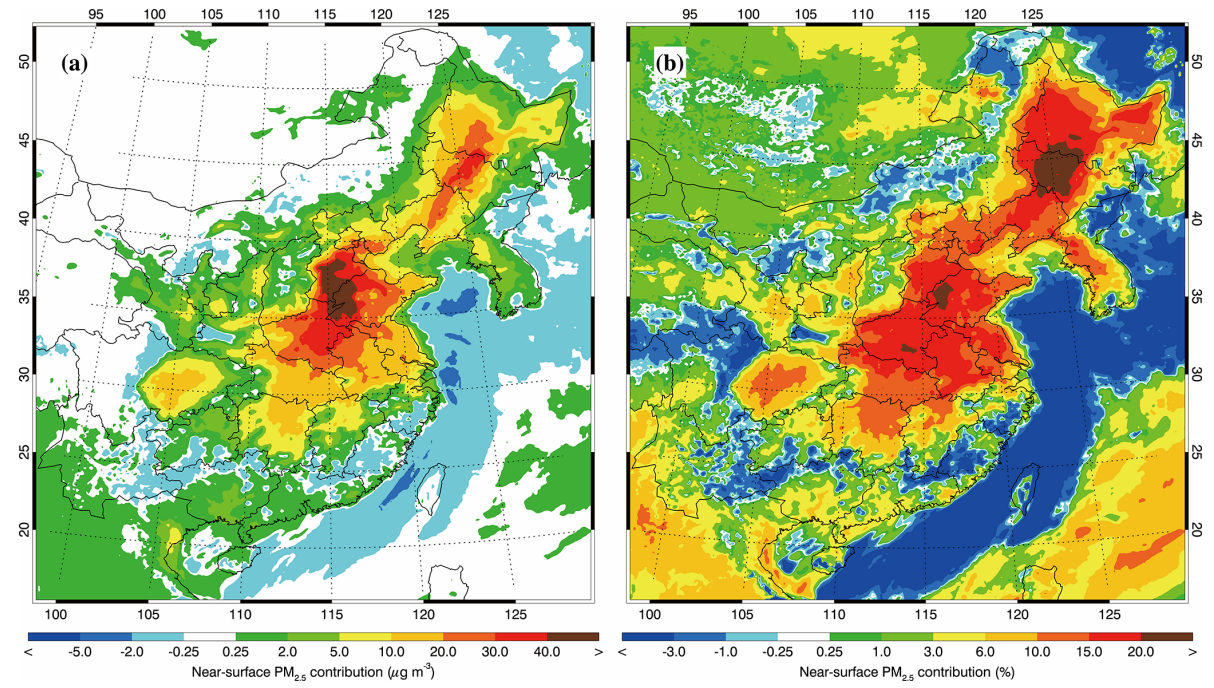

Figure 14. Average near-surface (a) absolute and (b) relative $\mathrm{PM}_{2.5}$ contribution caused by the ALW-HET from 5 December 2015 to 4 January 2016.

part of the NCP, and on average, the $\mathrm{PM}_{2.5}$ contribution of the ALW-HET is $21.7 \mu \mathrm{g} \mathrm{m}^{-3}$ (or $15.9 \%$ ), less than the total enhancement of $25.1 \mathrm{\mu g} \mathrm{m}^{-3}$ (or $18.4 \%$ ) from sulfate, nitrate, ammonium, and SOA. The inconsistency indicates that the ALW-HET induced SA enhancement causes a decrease in primary aerosols. Figure 15a and $\mathrm{b}$ show the percentage decrease in black carbon (BC) and primary organic aerosols (POA) as a function of bin $\left[\mathrm{PM}_{2.5}\right]$, respectively. Interestingly, the average $\mathrm{BC}$ and POA concentrations are decreased by $5.1 \%$ and $5.2 \%$ due to the ALW-HET, respectively. The ALW-HET induced SA enhancement augments the particle size and should increase the AOD. However, on the contrary, the ALW-HET decreases the AOD, although considerably in- creasing the Reff (Fig. 16a and b). The reason is that the enhanced SA enlarges particle sizes, facilitating the coagulation to decrease the aerosol number concentration and surface area, as shown in Fig. 16c and d. Hence, the decreased AOD and increased Reff due to the ALW-HET enhance the SWDOWN and TSFC, further increasing the PBLH and decreasing near-surface primary aerosols, as shown in Fig. 17.

It is worth noting that the ALW content (ALWC) and aerosol composition are mutually influenced; i.e., the ALWC depends on the existence of hydroscopic aerosols (mainly inorganic components) and the RH in the atmosphere, and the SA, particularly inorganic components, formed via heterogeneous and aqueous reactions involving the ALW, further 

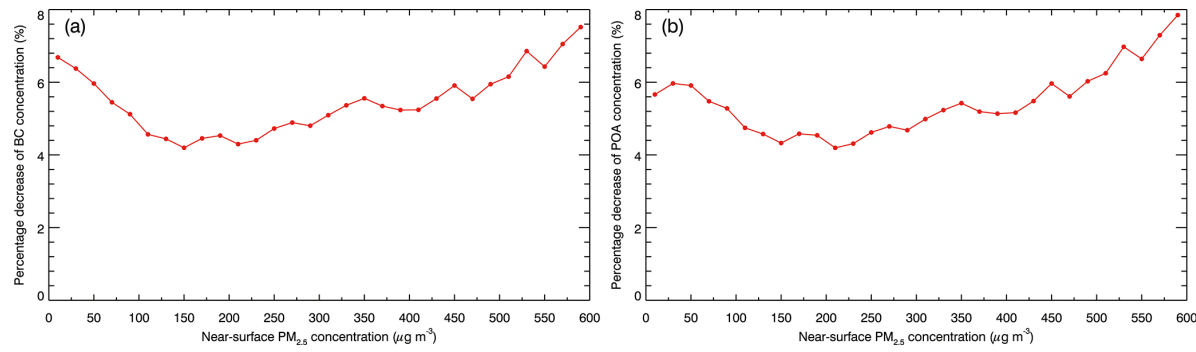

Figure 15. Average percentage decrease in (a) BC and (b) POA concentrations caused by the ALW-HET as a function of the near-surface $\left[\mathrm{PM}_{2.5}\right]$ in NCP from 5 December 2015 to 4 January 2016.
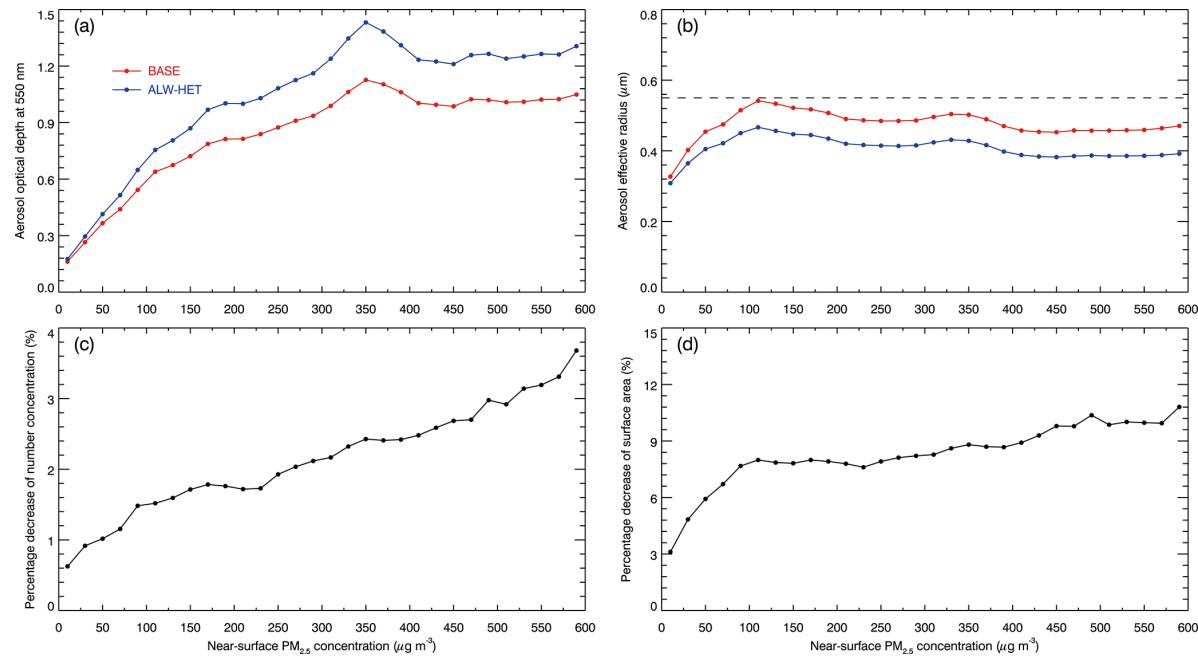

Figure 16. Average variations in (a) AOD and (b) Reff in $f_{\text {base }}$ (red line) and $f_{\text {alw_het0 }}$ (blue line), respectively, and average percentage decrease in near-surface (c) aerosol number concentration and (d) surface area caused by the ALW-HET as a function of bin [PM 2.5$]$ in NCP from 5 December 2015 to 4 January 2016.

increases the ALWC. Hence the initial hydroscopic aerosols might play a seeding role in the contribution of the ALWHET, likely constituting the most important factor in determining the ALWC and additional SA formed via heterogeneous or aqueous reactions. However, in model simulations, the initial hydroscopic aerosols or the seed particles are insignificant to the ALWC, since even without consideration of multiphase formation, the other processes still dominate the hydroscopic aerosol concentration in the atmosphere, including direct emissions, nucleation, condensation, etc., particularly after model spin-up. Therefore, the effect of initial hydroscopic aerosols or seed particles on the ALW and additional heterogeneous SA is generally negligible.

\subsubsection{ALW total effect}

Above discussions have shown that the ALW influences nearsurface $\left[\mathrm{PM}_{2.5}\right]$ through complicated physical and chemical processes, which interact with each other. Figure 18 shows the near-surface $\mathrm{PM}_{2.5}$ contribution of the total ALW effect (hereafter referred as to ALW-TOT) during the haze episode, evaluated by differentiating $f_{\text {base }}$ and $f_{\text {alw_tot } 0 \text {. The ALW- }}$
TOT plays an important role in the $\mathrm{PM}_{2.5}$ formation during the wintertime haze pollution in the NCP, with an average contribution of $23.8 \mu \mathrm{g} \mathrm{m}^{-3}$ (or $17.5 \%$ ), ranging from 5 to over $40 \mu \mathrm{g} \mathrm{m}^{-3}$. About $78 \%$ of the enhanced near-surface $\left[\mathrm{PM}_{2.5}\right]$ due to the ALW-TOT is contributed by secondary inorganic aerosols, in which the contributions from sulfate, nitrate, and ammonium are $45 \%, 14 \%$, and $19 \%$, respectively, and around $32 \%$ is contributed by SOA. Therefore, about $10 \%$ of near-surface $\left[\mathrm{PM}_{2.5}\right]$ enhancement from SA is counterbalanced by the decrease in the primary aerosols. Therefore, the ALW induced enhancement of near-surface $\left[\mathrm{PM}_{2.5}\right]$ is overwhelmingly determined by the ALW-HET, and the ALW-ARF and ALW-J are subject to decreasing $\left[\mathrm{PM}_{2.5}\right]$.

Figure 19 shows the variation in near-surface $\left[\mathrm{PM}_{2.5}\right]$ caused by the ALW-TOT, ALW-HET, ALW-ARF, and ALW$\mathrm{J}$ as a function of bin near-surface RH in the NCP during the haze episode to further assess the ALW effect. The hourly near-surface RH in $f_{\text {base }}$ is first divided into 28 bins, ranging from $30 \%$ to $100 \%$, with an interval of $2.5 \%$. The $\mathrm{PM}_{2.5}$ contribution from the four sensitivity simulations is assembled in the same grid cell as the bin $\mathrm{RH}$, and an average of 

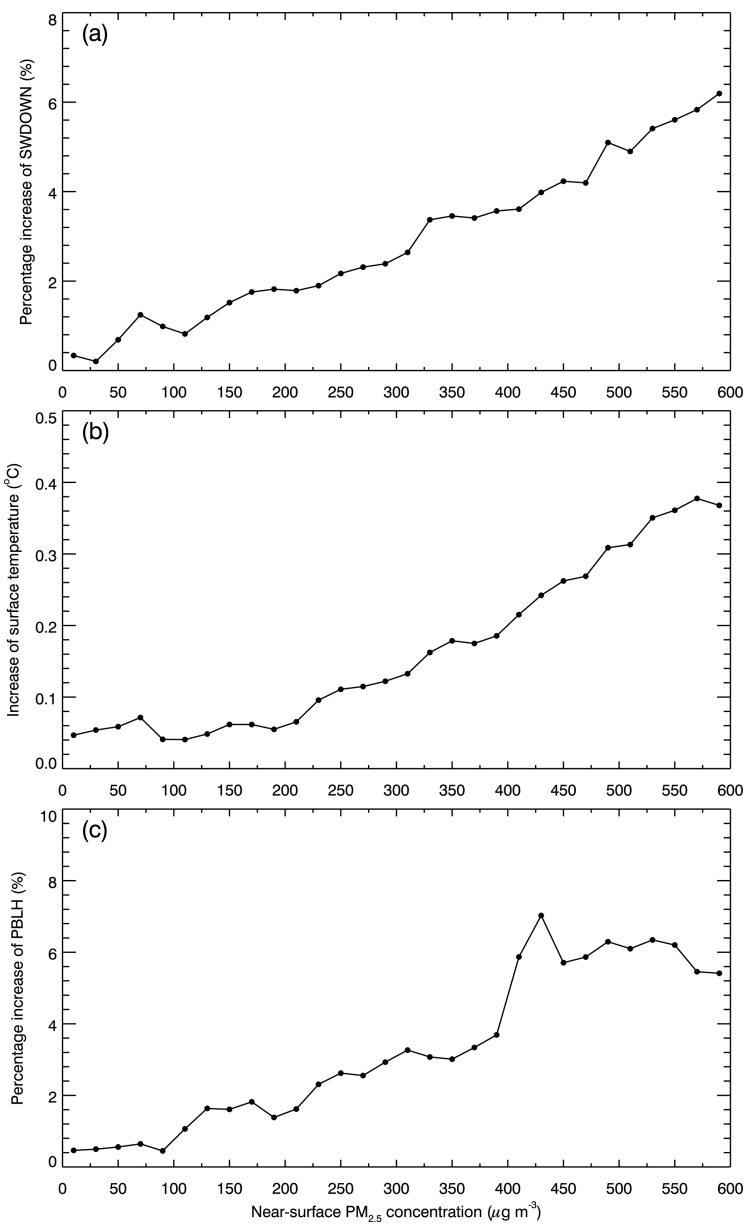

Figure 17. Average (a) percentage increase in SWDOWN at the ground surface, (b) increase in TSFC, and (c) percentage increase in PBLH caused by the ALW-HET as a function of the near-surface $\left[\mathrm{PM}_{2.5}\right]$ in NCP during daytime from 5 December 2015 to 4 January 2016.

$\mathrm{PM}_{2.5}$ contribution in each bin is calculated. The ALW does not continuously increase near-surface $\left[\mathrm{PM}_{2.5}\right]$ with the RH. When the RH is less than $80 \%$, the near-surface $\mathrm{PM}_{2.5}$ contribution of the ALW-TOT generally increases rapidly with the RH. However, when the RH exceeds $80 \%$, the contribution commences to decrease and fluctuates between 20 and $30 \mu \mathrm{g} \mathrm{m}^{-3}$, showing the effect of high occurrence frequencies of precipitation. In addition, the ALW-HET dominates the $\mathrm{PM}_{2.5}$ contribution, particularly with RH being less than $50 \%$. The ALW-RAD generally decreases $\left[\mathrm{PM}_{2.5}\right]$ slightly with the RH less than $52.5 \%$ and vice versa with the RH more than $52.5 \%$. The $\mathrm{PM}_{2.5}$ contribution of the ALW-J is negative and less than $1.5 \mu \mathrm{g} \mathrm{m}^{-3}$, except when the RH is between $92.5 \%$ and $97.5 \%$.

\section{Conclusions and summaries}

The good relationships between near-surface $\left[\mathrm{PM}_{2.5}\right]$ concentration and RH during the wintertime of 2015 in the NCP indicate the possibility that high RH plays an important role in the $\mathrm{PM}_{2.5}$ formation during the haze pollution. A severe haze pollution episode from 5 December 2015 to 4 January 2016 is simulated using the WRF-Chem Model to investigate the impact of ALW caused by the accumulated moisture on near surface $\left[\mathrm{PM}_{2.5}\right]$ in the NCP. The air over the NCP during the haze episode is humid, with an average simulated $\mathrm{RH}$ of about $71 \%$. In general, the WRF-Chem Model reproduces the temporal variations in RH reasonably well compared to observations at three sites in the NCP, although the model biases still exist due to the uncertainties in simulated meteorological fields.

The FSA method is used to evaluate the contribution of the ALW effect on ARF, photochemistry, and heterogeneous reactions to the wintertime $\mathrm{PM}_{2.5}$ concentration in the NCP. Model results show that the ALW substantially increases the daytime AOD with an average contribution of $46 \%$ in the NCP during the episode, enhancing the aerosol backward scattering, and also augments the Reff from $0.31 \mu \mathrm{m}$ to $0.48 \mu \mathrm{m}$, approaching the peak band of solar radiation, favoring the aerosol forward scattering. The ALW does not significantly attenuate the incoming solar radiation at the ground surface to enhance the ARF, and the average near-surface $\mathrm{PM}_{2.5}$ contribution of the ALW-ARF is about $1.1 \mu \mathrm{g} \mathrm{m}^{-3}$ in the NCP during the episode. Therefore, the ALW-ARF is not an important factor for heavy haze formation, and its contribution relies on the relative importance of the ALW induced enhancement of aerosol backward and forward scattering. The ALW generally decreases the photolysis rate at the surface level due to enhanced backward aerosol scattering, but the favored forward scattering still possibly accelerates the photolysis. Additionally, the ALW increases the photolysis rate in the upper layer and above the PBL. On average, the ALW decreases near-surface daytime $\mathrm{O}_{3}$ concentrations by $0.20 \mu \mathrm{g} \mathrm{m}^{-3}$ and $\left[\mathrm{PM}_{2.5}\right]$ by $0.87 \mu \mathrm{g} \mathrm{m}^{-3}$, playing a minor role in mitigating the haze pollution.

The ALW substantially enhances the SA formation by serving as an important medium for liquid-phase and heterogeneous reactions. The ALW contribution to near-surface sulfate, nitrate, ammonium, and SOA concentrations is $71 \%$, $10 \%, 26 \%$, and $48 \%$ in the NCP during the episode, respectively. However, the enhanced SA due to the ALW-HET enlarges particle sizes to facilitate the coagulation, decreasing the aerosol number concentration and surface area and further AOD. Therefore, the decreased AOD and increased Reff enhance the incoming solar radiation reaching the ground surface, further increasing the surface temperature and PBLH and decreasing near-surface primary aerosols. The ALWHET contributes $15.9 \%$ of near-surface $\left[\mathrm{PM}_{2.5}\right.$ ], less than the total SA enhancement of $18.4 \%$, and the rest is counterbalanced by the decrease in primary aerosols. 

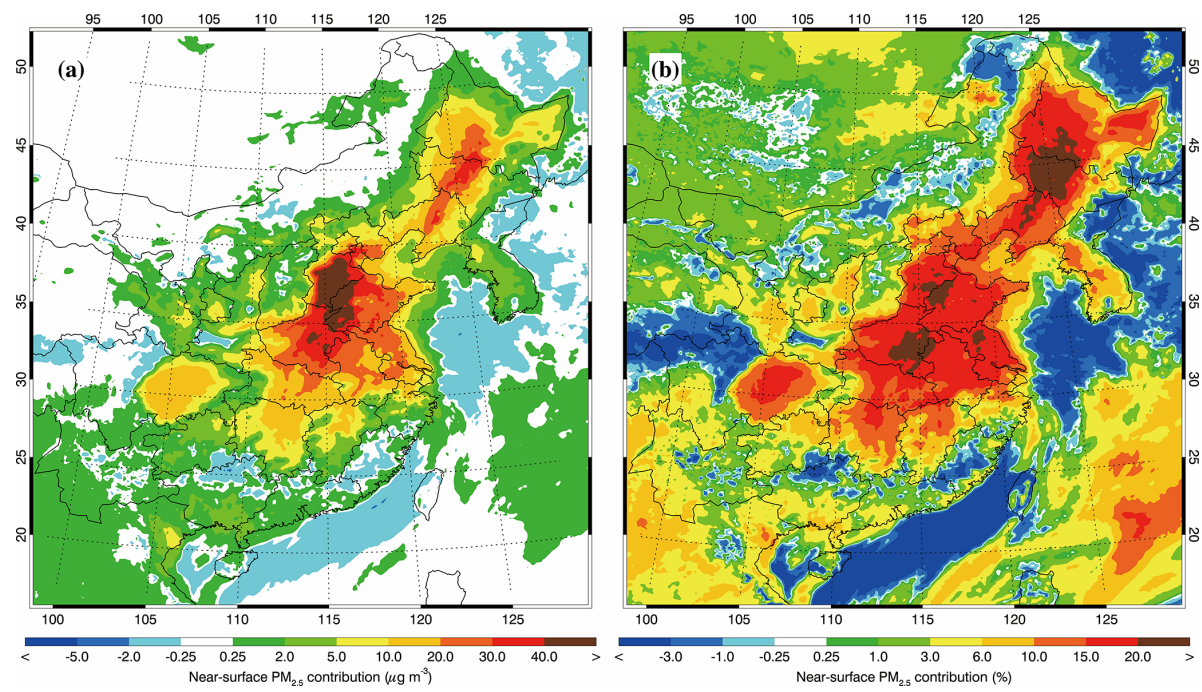

Figure 18. Average near-surface (a) absolute and (b) relative $\mathrm{PM}_{2.5}$ contribution caused by the ALW-TOT from 5 December 2015 to 4 January 2016.

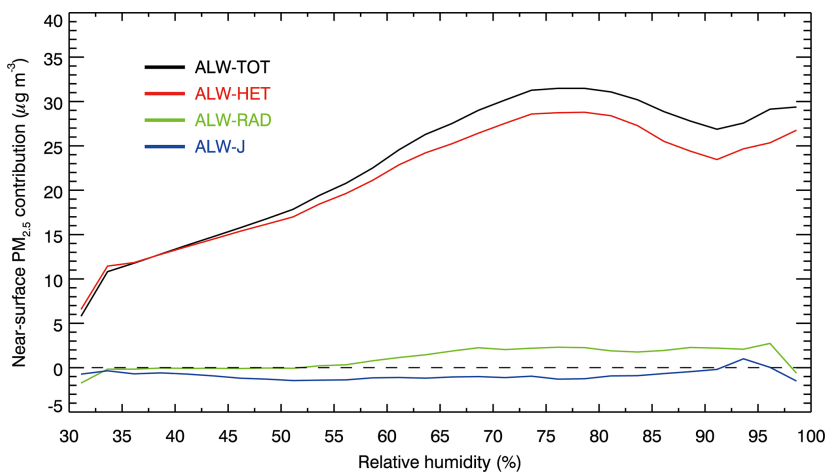

Figure 19. Average contributions to near-surface $\left[\mathrm{PM}_{2.5}\right]$ caused by the ALW-TOT (black line), ALW-HET (red line), ALW-RAD (green line), and ALW-J (blue line) as a function of the RH in NCP from 5 December 2015 to 4 January 2016.

The near-surface $\mathrm{PM}_{2.5}$ contribution of the ALW total effect is $17.5 \%$ in the NCP, indicating that ALW plays an important role in the $\mathrm{PM}_{2.5}$ formation during the wintertime haze pollution. Moreover, the ALW-HET overwhelmingly dominates the $\mathrm{PM}_{2.5}$ enhancement due to the ALW. The ALW does not consistently enhance near-surface $\left[\mathrm{PM}_{2.5}\right]$ with increasing RH. When the RH exceeds $80 \%$, the contribution of the ALW commences to decrease, being caused by the high occurrence frequencies of precipitation.

Although the model performs reasonably well in simulating air pollutants, aerosol species and optical properties, and $\mathrm{RH}$ during the episode in the NCP, the uncertainties from meteorological fields and the emission inventory still exist, leading to model biases. In addition, a simulation period of 1 month might not be sufficient for providing a comprehensive view of the ALW effect on the $\mathrm{PM}_{2.5}$ formation. More wintertime case studies will need to be performed in the future to further investigate the ALW effect.

Data availability. The real-time $\mathrm{PM}_{2.5}, \mathrm{O}_{3}, \mathrm{SO}_{2}, \mathrm{NO}_{2}$, and $\mathrm{CO}$ observations are accessible for the public on the website http://106. 37.208.233:20035/ (last access: 16 May 2018; China MEP, 2013a). One can also access the historic profile of observed ambient pollutants through visiting http://www.aqistudy.cn/ (last access: 16 May 2018; China MEP, 2013b).

Author contributions. GL, as the contact author, provided the ideas and financial support, developed the model code, verified the conclusions, and revised the paper. JW conducted research, designed the experiments, carried our the methodology, performed the simulation, processed the data, prepared the data visualization, and prepared the paper, with contributions from all authors. NB provided the treatment of meteorological data, analyzed the study data, validated the model performance, and reviewed the paper. BH provided the observation data used in the study, synthesized the observation, and reviewed the paper. SL, MZ, QW, ZL, and YW provided the data and the primary data process and reviewed the paper. $\mathrm{XL}, \mathrm{LL}$, and TF analyzed the initial simulation data, visualized the model results, and reviewed the paper. JC, XT, and JW provided critical reviews pre-publication stage. LTM provided a critical preview and financial support and revised the paper.

Competing interests. The authors declare that they have no conflict of interest.

Special issue statement. This article is part of the special issue "Regional transport and transformation of air pollution in eastern China". It does not belong to a conference. 
Acknowledgements. This work is financially supported by the National Key R\&D Plan (Quantitative Relationship and Regulation Principle between Regional Oxidation Capacity of Atmospheric and Air Quality - 2017YFC0210000) and the National Research Program for Key Issues in Air Pollution Control (DQGG0105). Luisa Molina acknowledges support from US NSF Award 1560494.

Financial support. This research has been supported by the National Key R\&D Plan (Quantitative Relationship and Regulation Principle between Regional Oxidation Capacity of Atmospheric and Air Quality; grant no. 2017YFC0210000) and the U.S. National Science Foundation (grant no. 1560494).

Review statement. This paper was edited by Renyi Zhang and reviewed by three anonymous referees.

\section{References}

Ackerman, T. P.: Model of effect of aerosols on urban climates with particular applications to Los-angeles basin, J. Atmos. Sci., 34, 531-547, https://doi.org/10.1175/15200469(1977)034<0531:amoteo>2.0.co;2, 1977.

Ackerman, T. P. and Baker, M. B.: Shortwave radiative effects of unactivated aerosol-particles in clouds, J. Appl. Meteorol., 16, 63-69, https://doi.org/10.1175/15200450(1977)016<0063:sreoua >2.0.co;2, 1977.

Bei, N. F., Li, G. H., Huang, R. J., Cao, J. J., Meng, N., Feng, T., Liu, S. X., Zhang, T., Zhang, Q., and Molina, L. T.: Typical synoptic situations and their impacts on the wintertime air pollution in the Guanzhong basin, China, Atmos. Chem. Phys., 16, 7373-7387, https://doi.org/10.5194/acp-16-7373-2016, 2016a.

Bei, N. F., Xiao, B., Meng, N., and Feng, T.: Critical role of meteorological conditions in a persistent haze episode in the Guanzhong basin, China, Sci. Total Environ., 550, 273-284, https://doi.org/10.1016/j.scitotenv.2015.12.159, $2016 \mathrm{~b}$.

Bei, N. F., Wu, J. R., Elser, M., Feng, T., Cao, J. J., El-Haddad, I., Li, X., Huang, R. J., Li, Z. Q., Long, X., Xing, L., Zhao, S. Y., Tie, X. X., Prevot, A. S. H., and Li, G. H.: Impacts of meteorological uncertainties on the haze formation in Beijing-Tianjin-Hebei (BTH) during wintertime: a case study, Atmos. Chem. Phys., 17, 1457914591, https://doi.org/10.5194/acp-17-14579-2017, 2017.

Blando, J. D. and Turpin, B. J.: Secondary organic aerosol formation in cloud and fog droplets: a literature evaluation of plausibility, Atmos. Environ., 34, 1623-1632, https://doi.org/10.1016/s1352-2310(99)00392-1, 2000.

Carrico, C. M., Kus, P., Rood, M. J., Quinn, P. K., and Bates, T. S.: Mixtures of pollution, dust, sea salt, and volcanic aerosol during ACE-Asia: Radiative properties as a function of relative humidity, J. Geophys. Res.-Atmos., 108, 8650, https://doi.org/10.1029/2003jd003405, 2003

Chan, C. K. and Yao, X.: Air pollution in mega cities in China, Atmos. Environ., 42, 1-42, 2008.

Chang, W. L., Brown, S. S., Stutz, J., Middlebrook, A. M., Bahreini, R., Wagner, N. L., Dube, W. P., Pollack, I. B., Ryerson, T. B., and Riemer, N.: Evaluating $\mathrm{N}_{2} \mathrm{O}_{5}$ heterogeneous hydrolysis pa- rameterizations for CalNex 2010, J. Geophys. Res.-Atmos., 121, 5051-5070, https://doi.org/10.1002/2015jd024737, 2016.

Chen, F. and Dudhia, J.: Coupling an advanced land surfacehydrology model with the Penn State-NCAR MM5 modeling system. Part I: Model implementation and sensitivity, Mon. Weather Rev., 129, 569-585, 2001.

Cheng, Y., He, K. B., Du, Z. Y., Zheng, M., Duan, F. K., and Ma, Y. L.: Humidity plays an important role in the $\mathrm{PM}_{2.5}$ pollution in Beijing, Environ. Pollut., 197, 68-75, https://doi.org/10.1016/j.envpol.2014.11.028, 2015.

Cheng, Y. F., Wiedensohler, A., Eichler, H., Heintzenberg, J., Tesche, M., Ansmann, A., Wendisch, M., Su, H., Althausen, D., Herrmann, H., Gnauk, T., Bruggemann, E., Hu, M., and Zhang, Y. H.: Relative humidity dependence of aerosol optical properties and direct radiative forcing in the surface boundary layer at Xinken in Pearl River Delta of China: An observation based numerical study, Atmos. Environ., 42, 6373-6397, https://doi.org/10.1016/j.atmosenv.2008.04.009, 2008.

Chou, M.-D. and Suarez, M. J.: A solar radiation parameterization for atmospheric studies, NASA Tech. Rep. NASA/TM-199910460, 15, 38 pp., 1999.

Chou, M.-D. and Suarez, M. J.: A thermal infrared radiation parameterization for atmospheric studies, NASA/TM-2001-104606, 19, 55 pp., 2001.

Cocker, D. R., Clegg, S. L., Flagan, R. C., and Seinfeld, J. H.: The effect of water on gas-particle partitioning of secondary organic aerosol. Part I: alpha-pinene/ozone system, Atmos. Environ., 35, 6049-6072, https://doi.org/10.1016/s1352-2310(01)004046, 2001a.

Cocker, D. R., Flagan, R. C., and Seinfeld, J. H.: Stateof-the-art chamber facility for studying atmospheric aerosol chemistry, Environ. Sci. Technol., 35, 2594-2601, https://doi.org/10.1021/es0019169, 2001b.

Cocker, D. R., Mader, B. T., Kalberer, M., Flagan, R. C., and Seinfeld, J. H.: The effect of water on gas-particle partitioning of secondary organic aerosol: II. m-xylene and 1,3,5trimethylbenzene photooxidation systems, Atmos. Environ., 35, 6073-6085, https://doi.org/10.1016/s1352-2310(01)00405$8,2001 \mathrm{c}$.

Covert, D. S., Charlson, R. J., and Ahlquist, N. C.: A Study of the Relationship of Chemical Composition and Humidity to Light Scattering by Aerosols, J. Appl. Meteorol., 11, 968-976, 1972.

Dickerson, R. R., Kondragunta, S., Stenchikov, G., Civerolo, K. L., Doddridge, B. G., and Holben, B. N.: The impact of aerosols on solar ultraviolet radiation and photochemical smog, Science, 278, 827-830, https://doi.org/10.1126/science.278.5339.827, 1997.

Ding, Y. H., Wu, P., Liu, Y. J., and Song, Y. F.: Environmental and Dynamic Conditions for the Occurrence of Persistent Haze Events in North China, Engineering, 3, 266-271, https://doi.org/10.1016/j.eng.2017.01.009, 2017.

Flocas, H., Kelessis, A., Helmis, C., Petrakakis, M., Zoumakis, M., and Pappas, K.: Synoptic and local scale atmospheric circulation associated with air pollution episodes in an urban Mediterranean area, Theo. Appl. Climatol., 95, 265-277, https://doi.org/10.1007/s00704-008-0005-9, 2009.

Fu, G. Q., Xu, W. Y., Yang, R. F., Li, J. B., and Zhao, C. S.: The distribution and trends of fog and haze in the North China Plain 
over the past 30 years, Atmos. Chem. Phys., 14, 11949-11958, https://doi.org/10.5194/acp-14-11949-2014, 2014.

Fu, T. M., Jacob, D. J., Wittrock, F., Burrows, J. P., Vrekoussis, M., and Henze, D. K.: Global budgets of atmospheric glyoxal and methylglyoxal, and implications for formation of secondary organic aerosols, J. Geophys. Res.-Atmos., 113, D15303, https://doi.org/10.1029/2007jd009505, 2008.

Gabusi, V., Pisoni, E., and Volta, M.: Factor separation in air quality simulations, Ecol. Model., 218, 383-392, https://doi.org/10.1016/j.ecolmodel.2008.07.030, 2008.

Guenther, A., Karl, T., Harley, P., Wiedinmyer, C., Palmer, P. I., and Geron, C.: Estimates of global terrestrial isoprene emissions using MEGAN (Model of Emissions of Gases and Aerosols from Nature), Atmos. Chem. Phys., 6, 3181-3210, https://doi.org/10.5194/acp-6-3181-2006, 2006.

Guo, S., Hu, M., Zamora, M. L., Peng, J. F., Shang, D. J., Zheng, J., Du, Z. F., Wu, Z., Shao, M., Zeng, L. M., Molina, M. J., and Zhang, R. Y.: Elucidating severe urban haze formation in China, P. Natl. Acad. Sci. USA, 111, 17373-17378, https://doi.org/10.1073/pnas.1419604111, 2014.

Hallquist, M., Wenger, J. C., Baltensperger, U., Rudich, Y., Simpson, D., Claeys, M., Dommen, J., Donahue, N. M., George, C., Goldstein, A. H., Hamilton, J. F., Herrmann, H., Hoffmann, T., Iinuma, Y., Jang, M., Jenkin, M. E., Jimenez, J. L., KiendlerScharr, A., Maenhaut, W., McFiggans, G., Mentel, T. F., Monod, A., Prevot, A. S. H., Seinfeld, J. H., Surratt, J. D., Szmigielski, R., and Wildt, J.: The formation, properties and impact of secondary organic aerosol: current and emerging issues, Atmos. Chem. Phys., 9, 5155-5236, https://doi.org/10.5194/acp-9-51552009, 2009.

Hastings, W. P., Koehler, C. A., Bailey, E. L., and De Haan, D. O.: Secondary organic aerosol formation by glyoxal hydration and oligomer formation: Humidity effects and equilibrium shifts during analysis, Environ. Sci. Technol., 39, 8728-8735, https://doi.org/10.1021/es0504461, 2005.

He, K. B., Yang, F. M., Ma, Y. L., Zhang, Q., Yao, X. H., Chan, C. K., Cadle, S., Chan, T., and Mulawa, P.: The characteristics of $\mathrm{PM}_{2.5}$ in Beijing, China, Atmos. Environ., 35, 4959-4970, https://doi.org/10.1016/s1352-2310(01)00301-6, 2001.

Healy, R. M., Temime, B., Kuprovskyte, K., and Wenger, J. C.: Effect of Relative Humidity on Gas/Particle Partitioning and Aerosol Mass Yield in the Photooxidation of p-Xylene, Environ. Sci. Technol., 43, 1884-1889, https://doi.org/10.1021/es802404z, 2009.

Hong, S.-Y. and Lim, J.-O. J.: The WRF Single-Moment 6-Class Microphysics Scheme (WSM6), Asia-Pacific, J. Atmos. Sci., 42, 129-151, 2006.

Horowitz, L. W., Walters, S., Mauzerall, D. L., Emmons, L. K., Rasch, P. J., Granier, C., Tie, X. X., Lamarque, J. F., Schultz, M. G., Tyndall, G. S., Orlando, J. J., and Brasseur, G. P.: A global simulation of tropospheric ozone and related tracers: Description and evaluation of MOZART, version 2, J. Geophys. Res.-Atmos., 108, 4784, https://doi.org/10.1029/2002jd002853, 2003.

Huang, R.-J., Zhang, Y., Bozzetti, C., Ho, K.-F., Cao, J.-J., Han, Y., Daellenbach, K. R., Slowik, J. G., Platt, S. M., Canonaco, F., Zotter, P., Wolf, R., Pieber, S. M., Bruns, E. A., Crippa, M., Ciarelli, G., Piazzalunga, A., Schwikowski, M., Abbaszade, G., SchnelleKreis, J., Zimmermann, R., An, Z., Szidat, S., Baltensperger, U., El Haddad, I., and Prévôt, A. S. H.: High secondary aerosol con- tribution to particulate pollution during haze events in China, Nature, 514, 218-222, https://doi.org/10.1038/nature13774, 2014.

Im, J. S., Saxena, V. K., and Wenny, B. N.: An assessment of hygroscopic growth factors for aerosols in the surface boundary layer for computing direct radiative forcing, J. Geophys. Res.-Atmos., 106, 20213-20224, https://doi.org/10.1029/2000jd000152, 2001.

Jacobson, M. Z.: Studying the effects of aerosols on vertical photolysis rate coefficient and temperature profiles over an urban airshed, J. Geophys. Res.-Atmos., 103, 10593-10604, https://doi.org/10.1029/98jd00287, 1998.

Jacobson, M. Z.: Analysis of aerosol interactions with numerical techniques for solving coagulation, nucleation, condensation, dissolution, and reversible chemistry among multiple size distributions, J. Geophys. Res.-Atmos., 107, 4366, https://doi.org/10.1029/2001jd002044, 2002.

Janjicè, Z. I.: Nonsingular Implementation of the Mellor - Yamada Level 2.5 Scheme in the NCEP Meso Model, Ncep Office Note, 436, 2002.

Jia, L. and Xu, Y. F.: Effects of Relative Humidity on Ozone and Secondary Organic Aerosol Formation from the Photooxidation of Benzene and Ethylbenzene, Aerosol Sci. Technol., 48, 1-12, https://doi.org/10.1080/02786826.2013.847269, 2014.

Kamens, R. M., Zhang, H. F., Chen, E. H., Zhou, Y., Parikh, H. M., Wilson, R. L., Galloway, K. E., and Rosen, E. P.: Secondary organic aerosol formation from toluene in an atmospheric hydrocarbon mixture: Water and particle seed effects, Atmos. Environ., 45, 2324-2334, https://doi.org/10.1016/j.atmosenv.2010.11.007, 2011.

Kan, H. D., Chen, R. J., and Tong, S. L.: Ambient air pollution, climate change, and population health in China, Environ. Int. 42, 10-19, https://doi.org/10.1016/j.envint.2011.03.003, 2012.

Koehler, C. A., Fillo, J. D., Ries, K. A., Sanchez, J. T., and De Haan, D. O.: Formation of secondary organic aerosol by reactive condensation of furandiones, aldehydes, and water vapor onto inorganic aerosol seed particles, Environ. Sci. Technol., 38, 50645072, https://doi.org/10.1021/es034672b, 2004.

Kurokawa, J., Ohara, T., Morikawa, T., Hanayama, S., JanssensMaenhout, G., Fukui, T., Kawashima, K., and Akimoto, H.: Emissions of air pollutants and greenhouse gases over Asian regions during 2000-2008: Regional Emission inventory in Asia (REAS) version 2, Atmos. Chem. Phys., 13, 11019-11058, https://doi.org/10.5194/acp-13-11019-2013, 2013.

Li, G., Lei, W., Zavala, M., Volkamer, R., Dusanter, S., Stevens, P., and Molina, L. T.: Impacts of HONO sources on the photochemistry in Mexico City during the MCMA2006/MILAGO Campaign, Atmos. Chem. Phys., 10, 6551-6567, https://doi.org/10.5194/acp-10-6551-2010, 2010.

Li, G., Bei, N., Tie, X., and Molina, L. T.: Aerosol effects on the photochemistry in Mexico City during MCMA2006/MILAGRO campaign, Atmos. Chem. Phys., 11, 51695182, https://doi.org/10.5194/acp-11-5169-2011, 2011a.

Li, G., Zavala, M., Lei, W., Tsimpidi, A. P., Karydis, V. A., Pandis, S. N., agaratna, M. R., and Molina, L. T.: Simulations of organic aerosol concentrations in Mexico City using the WRF-CHEM model during the MCMA-2006/MILAGRO campaign, Atmos. Chem. Phys., 11, 3789-3809, https://doi.org/10.5194/acp-113789-2011, 2011b. 
Li, G., Lei, W., Bei, N., and Molina, L. T.: Contribution of garbage burning to chloride and $\mathrm{PM}_{2.5}$ in Mexico City, Atmos. Chem. Phys., 12, 8751-8761, https://doi.org/10.5194/acp12-8751-2012, 2012.

Li, G. H., Bei, N. F., Zavala, M., and Molina, L. T.: Ozone formation along the California Mexican border region during Cal-Mex 2010 field campaign, Atmos. Environ., 88, 370-389, https://doi.org/10.1016/j.atmosenv.2013.11.067, 2014.

Li, G., Bei, N., Cao, J., Huang, R., Wu, J., Feng, T., Wang, Y., Liu, S., Zhang, Q., Tie, X., and Molina, L. T.: A possible pathway for rapid growth of sulfate during haze days in China, Atmos. Chem. Phys., 17, 3301-3316, https://doi.org/10.5194/acp17-3301-2017, 2017a.

Li, N., Fu, T. M., Cao, J. J., Lee, S. C., Huang, X. F., He, L. Y., Ho, K. F., Fu, J. S., and Lam, Y. F.: Sources of secondary organic aerosols in the Pearl River Delta region in fall: Contributions from the aqueous reactive uptake of dicarbonyls, Atmos. Environ., 76, 200-207, https://doi.org/10.1016/j.atmosenv.2012.12.005, 2013.

Liggio, J., Li, S. M., and McLaren, R.: Reactive uptake of glyoxal by particulate matter, J. Geophys. Res.-Atmos., 110, D10304, https://doi.org/10.1029/2004jd005113, 2005.

Liu, Q., Jia, X. C., Quan, J. N., Li, J. Y., Li, X., Wu, Y. X., Chen, D., Wang, Z. F., and Liu, Y. G.: New positive feedback mechanism between boundary layer meteorology and secondary aerosol formation during severe haze events, Sci. Rep., 8, 6095, https://doi.org/10.1038/s41598-018-24366-3, 2018.

Ministry of Environmental Protection, China (China MEP): Air Quality Observation Real-time Release Platform of MEP Data Center, available at: http://106.37.208.233:20035/ (last access: 16 May 2018), 2013a.

Ministry of Environmental Protection, China (China MEP): Online Monitoring and Analysis Platform of China Air Quality, available at: http://www.aqistudy.cn/ (last access: 16 May 2018), 2013b.

Nguyen, T. B., Roach, P. J., Laskin, J., Laskin, A., and Nizkorodov, S. A.: Effect of humidity on the composition of isoprene photooxidation secondary organic aerosol, Atmos. Chem. Phys., 11, 6931-6944, https://doi.org/10.5194/acp-11-6931-2011, 2011.

Parrish, D. D. and Zhu, T.: Clean Air for Megacities, Science, 326, 674-675, https://doi.org/10.1126/science.1176064, 2009.

Pathak, R. K., Wang, T., and Wu, W. S.: Nighttime enhancement of $\mathrm{PM}_{2.5}$ nitrate in ammonia-poor atmospheric conditions in Beijing and Shanghai: Plausible contributions of heterogeneous hydrolysis of $\mathrm{N}_{2} \mathrm{O}_{5}$ and $\mathrm{HNO}_{3}$ partitioning, Atmos. Environ., 45, 1183-1191, https://doi.org/10.1016/j.atmosenv.2010.09.003, 2011.

Penner, J. E., Hegg, D., and Leaitch, R.: Unraveling the role of aerosols in climate change, Environ. Sci. Technol., 35, 332A340A, https://doi.org/10.1021/es0124414, 2001.

Pilinis, C., Seinfeld, J. H., and Grosjean, D.: Water content of atmospheric aerosols, Atmos. Environ., 23, 1601-1606, 1989.

Poulain, L., Wu, Z., Petters, M. D., Wex, H., Hallbauer, E., Wehner, B., Massling, A., Kreidenweis, S. M., and Stratmann, F.: Towards closing the gap between hygroscopic growth and $\mathrm{CCN}$ activation for secondary organic aerosols - Part 3: Influence of the chemical composition on the hygroscopic properties and volatile fractions of aerosols, Atmos. Chem. Phys., 10, 37753785, https://doi.org/10.5194/acp-10-3775-2010, 2010.
Quan, J. N., Gao, Y., Zhang, Q., Tie, X. X., Cao, J. J., Han, S. Q., Meng, J. W., Chen, P. F., and Zhao, D. L.: Evolution of planetary boundary layer under different weather conditions, and its impact on aerosol concentrations, Particuology, 11, 34-40, https://doi.org/10.1016/j.partic.2012.04.005, 2013.

Randles, C. A., Russell, L. M., and Ramaswamy, V.: Hygroscopic and optical properties of organic sea salt aerosol and consequences for climate forcing, Geophys. Res. Lett., 31, L16108, https://doi.org/10.1029/2004gl020628, 2004.

Riemer, N., Vogel, H., Vogel, B., Schell, B., Ackermann, I., Kessler, C., and Hass, H.: Impact of the heterogeneous hydrolysis of $\mathrm{N}_{2} \mathrm{O}_{5}$ on chemistry and nitrate aerosol formation in the lower troposphere under photosmog conditions, J. Geophys. Res.Atmos., 108, 4144, https://doi.org/10.1029/2002jd002436, 2003.

Seinfeld, J. H., Erdakos, G. B., Asher, W. E., and Pankow, J. F.: Modeling the formation of secondary organic aerosol (SOA). 2. The predicted effects of relative humidity on aerosol formation in the alpha-pinene-, beta-pinene-, sabinene-, Delta(3)-Carene, and cyclohexene-ozone systems, Environ. Sci. Technol., 35, 1806-1817, https://doi.org/10.1021/es001765+, 2001.

Seinfeld, J. H. and Pandis, S. N.: Atmospheric Chemistry and Physics: From Air Pollution to Climate Change, John Wiley \& Sons, USA, 1986.

Stein, U. and Alpert, P.: Factor separation in numerical simulations, J. Atmos. Sci., 50, 2107-2115, https://doi.org/10.1175/15200469(1993)050<2107:fsins>2.0.co;2, 1993.

Sun, Y., Wang, Z., Fu, P., Jiang, Q., Yang, T., Li, J., and Ge, X.: The impact of relative humidity on aerosol composition and evolution processes during wintertime in Beijing, China, Atmos. Environ., 77, 927-934, https://doi.org/10.1016/j.atmosenv.2013.06.019, 2013.

Tao, J. C., Zhao, C. S., Ma, N., and Liu, P. F.: The impact of aerosol hygroscopic growth on the single-scattering albedo and its application on the $\mathrm{NO}_{2}$ photolysis rate coefficient, Atmos. Chem. Phys., 14, 12055-12067, https://doi.org/10.5194/acp-14-120552014, 2014.

Tie, X. X., Huang, R. J., Cao, J. J., Zhang, Q., Cheng, Y. F., Su, H., Chang, D., Poschl, U., Hoffmann, T., Dusek, U., Li, G. H., Worsnop, D. R., and O'Dowd, C. D.: Severe Pollution in China Amplified by Atmospheric Moisture, Sci. Rep., 7, 15760, https://doi.org/10.1038/s41598-017-15909-1, 2017.

Volkamer, R., Martini, F. S., Molina, L. T., Salcedo, D., Jimenez, J. L., and Molina, M. J.: A missing sink for gas-phase glyoxal in Mexico City: Formation of secondary organic aerosol, Geophys. Res. Lett., 34, L19807, https://doi.org/10.1029/2007gl030752, 2007.

Wang, G., Zhang, R., Gomez, M. E., Yang, L., Zamora, M. L., Hu, M., Lin, Y., Peng, J., Guo, S., and Meng, J.: Persistent sulfate formation from London Fog to Chinese haze, P. Natl. Acad. Sci. USA, 113, 13630-13635, 2016.

Wang, Y. S., Yao, L., Wang, L. L., Liu, Z. R., Ji, D. S., Tang, G. Q., Zhang, J. K., Sun, Y., Hu, B., and Xin, J. Y.: Mechanism for the formation of the January 2013 heavy haze pollution episode over central and eastern China, Sci. China-Earth Sci., 57, 14-25, https://doi.org/10.1007/s11430-013-4773-4, 2014.

Weinhold, B.: Ozone nation - EPA standard panned by the people, Environ. Health. Persp., 116, A302-A305, 2008.

Wu, J. R., Li, G. H., Cao, J. J., Bei, N. F., Wang, Y. C., Feng, T., Huang, R. J., Liu, S. X., Zhang, Q., and Tie, X. X.: Con- 
tributions of trans-boundary transport to summertime air quality in Beijing, China, Atmos. Chem. Phys., 17, 2035-2051, https://doi.org/10.5194/acp-17-2035-2017, 2017.

Wu, J., Bei, N., Hu, B., Liu, S., Zhou, M., Wang, Q., Li, X., Liu, L., Feng, T., Liu, Z., Wang, Y., Cao, J., Tie, X., Wang, J., Molina, L. T., and Li, G.: Aerosol-radiation feedback deteriorates the wintertime haze in the North China Plain, Atmos. Chem. Phys., 19, 8703-8719, https://doi.org/10.5194/acp-19-8703-2019, 2019.

Wu, P., Ding, Y. H., and Liu, Y. J.: Atmospheric circulation and dynamic mechanism for persistent haze events in the Beijing-Tianjin-Hebei region, Adv. Atmos. Sci., 34, 429-440, https://doi.org/10.1007/s00376-016-6158-z, 2017.

Wu, Z. J., Wang, Y., Tan, T. Y., Zhu, Y. S., Li, M. R., Shang, D. J., Wang, H. C., Lu, K. D., Guo, S., Zeng, L. M., and Zhang, Y. H.: Aerosol Liquid Water Driven by Anthropogenic Inorganic Salts: Implying Its Key Role in Haze Formation over the North China Plain, Environ. Sci. Technol. Lett., 5, 160-166, https://doi.org/10.1021/acs.estlett.8b00021, 2018.

Xing, L., Wu, J., Elser, M., Tong, S., Liu, S., Li, X., Liu, L., Cao, J., Zhou, J., El-Haddad, I., Huang, R., Ge, M., Tie, X., Préôt, A. S. H., and Li, G.: Wintertime secondary organic aerosol formation in Beijing-Tianjin-Hebei (BTH): contributions of HONO sources and heterogeneous reactions, Atmos. Chem. Phys., 19, 2343-2359, https://doi.org/10.5194/acp-19-2343-2019, 2019.

Xu, J. W., Martin, R. V., van Donkelaar, A., Kim, J., Choi, M., Zhang, Q., Geng, G., Liu, Y., Ma, Z., Huang, L., Wang, Y., Chen, H., Che, H., Lin, P., and Lin, N.: Estimating ground-level PM2.5 in eastern China using aerosol optical depth determined from the GOCI satellite instrument, Atmos. Chem. Phys., 15, 1313313144, https://doi.org/10.5194/acp-15-13133-2015, 2015.
Zhang, L., Sun, J. Y., Shen, X. J., Zhang, Y. M., Che, H., Ma, Q. L., Zhang, Y. W., Zhang, X. Y., and Ogren, J. A.: Observations of relative humidity effects on aerosol light scattering in the Yangtze River Delta of China, Atmos. Chem. Phys., 15, 84398454, https://doi.org/10.5194/acp-15-8439-2015, 2015.

Zhang, Q., Streets, D. G., Carmichael, G. R., He, K. B., Huo, H., Kannari, A., Klimont, Z., Park, I. S., Reddy, S., Fu, J. S., Chen, D., Duan, L., Lei, Y., Wang, L. T., and Yao, Z. L.: Asian emissions in 2006 for the NASA INTEX-B mission, Atmos. Chem. Phys., 9, 5131-5153, https://doi.org/10.5194/acp-9-5131-2009, 2009.

Zhang, R., Jing, J., Tao, J., Hsu, S.-C., Wang, G., Cao, J., Lee, C. S. L., Zhu, L., Chen, Z., Zhao, Y., and Shen, Z.: Chemical characterization and source apportionment of $\mathrm{PM}_{2.5}$ in Beijing: seasonal perspective, Atmos. Chem. Phys., 13, 7053-7074, https://doi.org/10.5194/acp-13-7053-2013, 2013.

Zhang, R. H., Li, Q., and Zhang, R. N.: Meteorological conditions for the persistent severe fog and haze event over eastern China in January 2013, Sci. China-Earth Sci., 57, 26-35, https://doi.org/10.1007/s11430-013-4774-3, 2014.

Zhao, J., Levitt, N. P., Zhang, R. Y., and Chen, J. M.: Heterogeneous reactions of methylglyoxal in acidic media: implications for secondary organic aerosol formation, Environ. Sci. Technol., 40, 7682-7687, 2006.

Zhou, Y., Zhang, H. F., Parikh, H. M., Chen, E. H., Rattanavaraha, W., Rosen, E. P., Wang, W. X., and Kamens, R. M.: Secondary organic aerosol formation from xylenes and mixtures of toluene and xylenes in an atmospheric urban hydrocarbon mixture: Water and particle seed effects (II), Atmos. Environ., 45, 3882-3890, https://doi.org/10.1016/j.atmosenv.2010.12.048, 2011. 